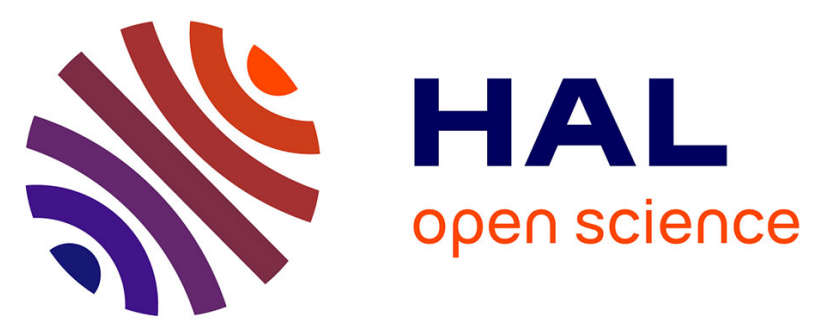

\title{
Development of an Open-GIS decision aid system for ecological and economical management of surface and groundwater resources in the Bistrita River Basin (Romania)
}

M. C. Trifu, Vasile Craciunescu, C. Rusu, A. Pandele, Josette Garnier, Gilles Billen, Emmanuel Ledoux

\section{To cite this version:}

M. C. Trifu, Vasile Craciunescu, C. Rusu, A. Pandele, Josette Garnier, et al.. Development of an Open-GIS decision aid system for ecological and economical management of surface and groundwater resources in the Bistrita River Basin (Romania). Hydrology and Earth System Sciences Discussions, 2007, 4 (4), pp.2035-2071. hal-00330806

\section{HAL Id: hal-00330806 https://hal.science/hal-00330806}

Submitted on 2 Jul 2007

HAL is a multi-disciplinary open access archive for the deposit and dissemination of scientific research documents, whether they are published or not. The documents may come from teaching and research institutions in France or abroad, or from public or private research centers.
L'archive ouverte pluridisciplinaire HAL, est destinée au dépôt et à la diffusion de documents scientifiques de niveau recherche, publiés ou non, émanant des établissements d'enseignement et de recherche français ou étrangers, des laboratoires publics ou privés. 
Hydrol. Earth Syst. Sci. Discuss., 4, 2035-2071, 2007 www.hydrol-earth-syst-sci-discuss.net/4/2035/2007/

(C) Author(s) 2007. This work is licensed under a Creative Commons License.
Hydrology and Earth System Sciences Discussions

Papers published in Hydrology and Earth System Sciences Discussions are under open-access review for the journal Hydrology and Earth System Sciences

\section{Development of an Open-GIS decision aid system for ecological and economical management of surface and groundwater resources in the Bistrita River Basin (Romania)}

M. C. Trifu ${ }^{1}$, V. Craciunescu ${ }^{2}$, C. Rusu ${ }^{3}$, A. Pandele ${ }^{1}$, J. Garnier ${ }^{4}$, G. Billen ${ }^{4}$, and E. Ledoux ${ }^{5}$

${ }^{1}$ National Institute of Hydrology and Water Management, 97, Sos. Bucureşti - Ploieşti, Sect. 1, Bucharest cod 013686, Romania

${ }^{2}$ National Administration of Meteorology, 97, Sos. Bucureşti - Ploieşti, Sect. 1, Bucharest cod 013686, Romania

${ }^{3}$ National Administration "Apele Romane", 6, Strada Edgar Quinet, sect. 1, Bucharest, cod 010018, Romania

${ }^{4}$ UMR Sisyphe-7619, Université Pierre \& Marie Curie, 4, place Jussieu, Tour 46/56, 75252 Paris, France

HESSD

4, 2035-2071, 2007

Open-GIS decision aid system for the Bistrita River Basin

M. C. Trifu et al.

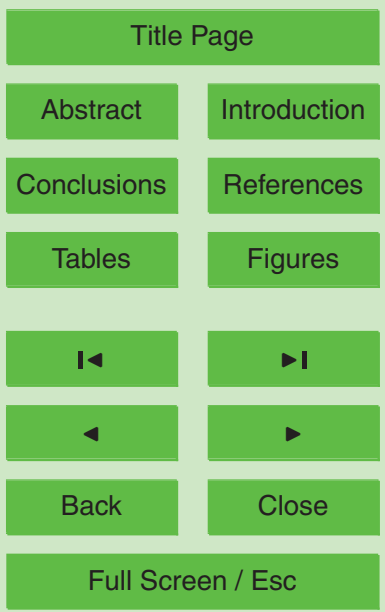

Printer-friendly Version

Interactive Discussion 
${ }^{5}$ UMR Sisyphe-7619, Ecole des Mines de Paris, Centre de Géosciences, 35, rue Saint Honoré, 77305, Fontainebleau, France

Received: 11 May 2007 - Accepted: 23 May 2007 - Published: 2 July 2007

Correspondence to: M. C. Trifu (cristrifu@yahoo.com)

\section{HESSD}

4, 2035-2071, 2007

Open-GIS decision aid system for the Bistrita River Basin

M. C. Trifu et al.

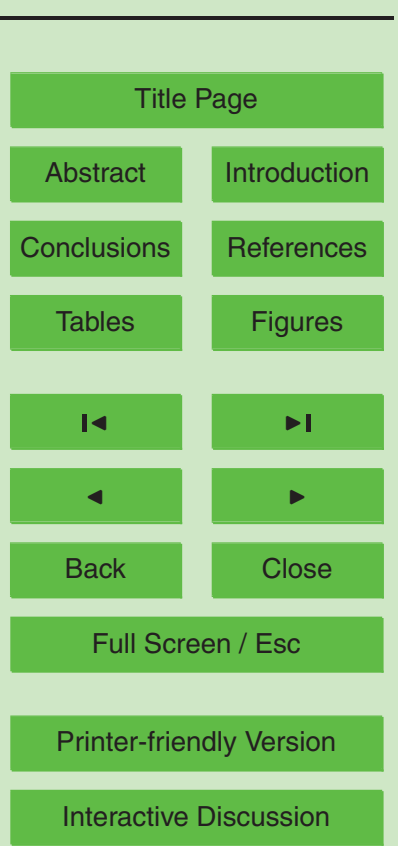




\section{Abstract}

The Bistrita River Basin (a length of $283 \mathrm{~km}$, a surface of $7039 \mathrm{~km}^{2}$, a mean discharge of $65 \mathrm{~m}^{3} / \mathrm{s}$ ) is one of the most important tributary of the Siret River, which is the second major affluent of the Danube River. Heavily influenced by hydraulic management and

5 highly polluted by agricultural and urban activities in some stretches, the Bistrita river has been studied in the framework of the Diminish Project (LIFE03 ENV/ RO/000539), funded by the Life Environment Program. The project aims to support the implementation of the EU Water Framework Directive and to combat the nutrient pollution by developing an integrated, on-line, GIS-based support system for the management of the water quality in relation with human activities, using socio-economical analysis, at the scale of the river catchments. Based on modeling approaches the decisional system allows to predict which strategy will lead to the most effective reduction of nutrient concentrations within the Bistrita hydrological network and of nutrient loads transported by the Siret River into the Danube.

15 The consequences of the nutrient pollution are discussed for two basin areas, from two points of view: i) the effects of point and diffuse pollution for surface and groundwater, on the basis of the basin response to the changing pressures over the river catchments (industrial, rural, urban, agricultural changes), ii) the economical valuation of environmental costs and cost-effectiveness of the measures, that can be proposed from socio-economic scenarios, for reaching the "good ecological status" of this river.

\section{Introduction}

Over the last 30 years, the conditions created by modern agriculture, urbanization and industrial activities, as main sources of pollution, have led to an increase in nutrients through human activity, both from diffuse and point sources, in surface and groundwater. Subsequently nutrient equilibrium has been also altered in many rivers in the world (Trifu et al., 2002; Billen et al., 1999; Volkswirt et al., 2004).
HESSD

4, 2035-2071, 2007

Open-GIS decision aid system for the Bistrita River Basin

M. C. Trifu et al.

Title Page

Abstract

Introduction

Conclusions

Tables

References

Figures

14

$\rightarrow$

Back

Close

Printer-friendly Version

Interactive Discussion 
In the downstream Danube basin, the nutrient pollution aspect is of great relevance due to the fact that presently, most areas from various river basins of Romania are subjected to water quality problems, especially related to agricultural and industrial pollution. As a consequence the nutrient pollution problem must be considered as a 5 large scale issue, and the whole territory of Romania has been therefore declared as a zone vulnerable to nutrient pollution.

This paper is part of the Life Diminish project (LIFE03 ENV/RO/000539: Development of an integrated basin management system in order to correlate water quantity and quality analysis with socio-economical analysis, using Open-GIS technology) hav10 ing the main purpose to develop and implement an action program, able to forecast nutrient pollution using different approaches : i) an on-line emission monitoring aimed at improving water quality in areas subject to nutrient pollution, ii) polluters have to be discouraged to maintain emissions regardless of the allowed maximum values; iii) public implication on the basin management plans must be increased before the adop15 tion of final decisions concerning the environmental necessary measures. The Water Framework Directive (WFD) requires a good knowledge of the many complex interactions between natural processes and human activities. Assessment of the pressure state - impact interaction and the relation to the economic consequences as well as the identification and quantification of possible measures for achieving the environmental objectives is facilitated using GIS (Geographical Information System) and mathematical modeling tools.

A completely integrated system, based on mathematical approach and Open-GIS technology has been elaborated, capable to inter-correlate information on long period of time and forecast the nutrient pollution in relation to human activities. Economical integrated into the system. Scenarios regarding the decrease of the pollution have been designed, such as the upgrade and the construction of sewage plants regarding point source pollution and rotation of crops or changes of land use concerning diffuse sources. These two kinds of scenarios represent the main measures to be taken for

HESSD

4, 2035-2071, 2007

Open-GIS decision aid system for the Bistrita River Basin

M. C. Trifu et al.

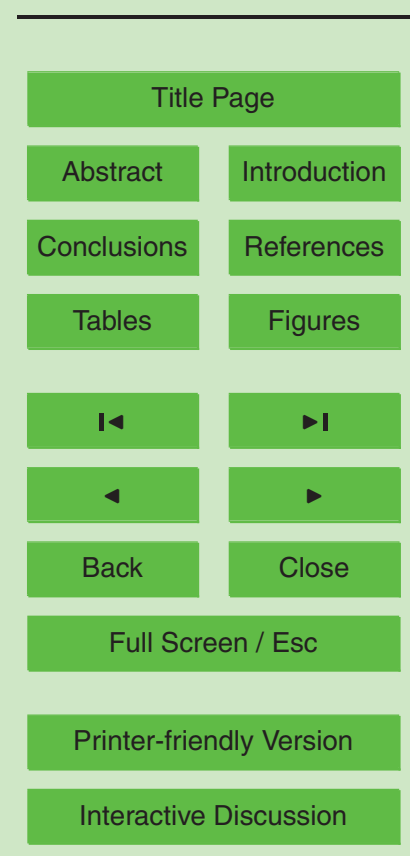

EGU 


\section{Study site}

The Bistrita River Basin is situated at the Eastern part of Romania and has an area of $7039 \mathrm{~km}^{2}$. The Bistrita River is one of the main tributaries of the Siret River (a length 5 of $283 \mathrm{~km}$, a surface of $7039 \mathrm{~km}^{2}$, a mean discharge of $65 \mathrm{~m}^{3} / \mathrm{s}$ ) (Fig. 1). The mean altitude of the basin is $919 \mathrm{~m}$ but the relief is massive in the upper part of the basin, and mountains of high altitude are found. After 1960, the middle and downstream part of the river were managed with 9 hydrotechnic reservoirs and 13 hydroelectric power plants.

10 The Bistrita River Basin has a population about 550000 inhabitants, from which some $55 \%$ live in urban areas (Fig. 2). Among the total population $43 \%$ are connected to the centralized water supply or sewage system. For nutrient balance calculations, the estimation of diffuse sources originated from the population is important, taking into account that only 10 agglomerations among a total of 375 localities have wastewater 15 treatment plants.

Due to high soil erosion within the basin, the phosphorus concentrations in the river are controlled by watershed diffuse sources.

Human activities, such as discharge of wastewater, hydrological management and intensification of agriculture, have disturbed the natural fluxes of nitrogen and phosphorus, resulting in eutrophication of the water system in the lower stretch of the river, with negative consequences for recreational amenities provided by the water course. The groundwater body GWSI03 $\left(600 \mathrm{~km}^{2}\right)$, precisely located in the downstream part of the Bistrita basin is also affected by agriculture through water infiltrations from the surface waters (Fig. 2). An important consequence is a decrease of groundwater quality and a
4, 2035-2071, 2007

Open-GIS decision aid system for the Bistrita River Basin

M. C. Trifu et al.

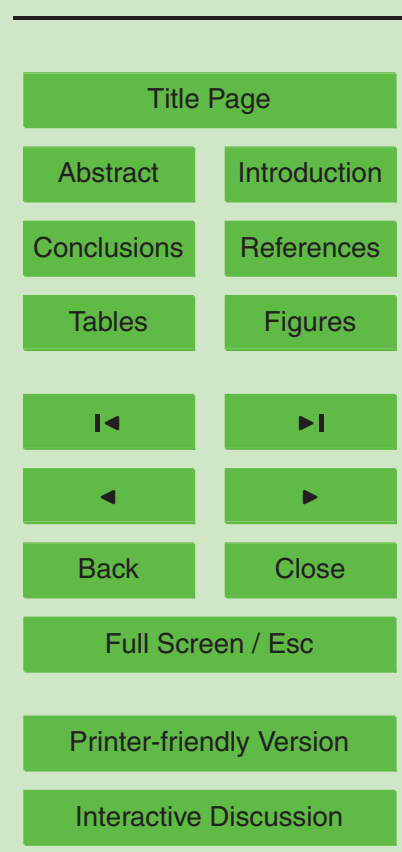




\section{Construction of the GIS data base}

The on-line Diminish system allows the establishment of a complex database developed in the GIS environment and provides the possibility to bring together different types of information into the same reference system. The structure of the dedicated

5 GIS database has been planned for the study of the evaluation and management of information (related to water quality management), as well as for the assessment of damages produced by pollution effects. Therefore, the database represented by the spatial geo-referenced information ensemble (satellite images, thematic maps, and series of the meteorological and hydrological parameters, other exogenous data) is structured 10 as a set of file-distributed quantitative and qualitative data. The GIS database contains info-layers in a relational structure, that are: sub-basins and basin limits; land topography ( $15 \mathrm{~m}$ cell size DEM); hydrographic and canal networks; transport network (roads, railways); localities; administrative boundaries; meteorological and hydrometrical gauge stations; points of interest (pollution sources, water quality control sections, wells, etc.); land cover/land use, updated from satellite images (Fig. 3).

We have chosen to develop a GIS database for the whole study area of the Bistrita basin using different cartographic documents at the scales 1:25000, 1:50 000, 1:200 000. Most of the thematic layers have been extracted from this classical mapping support. Due to the fact that, in most of the cases, the information on the maps is old-fashioned, it was necessary to update it on the basis of the recent satellite images (e.g. satellites: LANDSAT ETM+ (http://landsat.gsfc.nasa.gov/); TERRA/ASTER (http://asterweb.jpl.nasa.gov/); SPOT 5 (http://www.spot.com); images: the hydrographic network, land cover/land use) or by field measurements (several measurement campaigns were organized using GPS technology, necessary to set up the pointssources, wells location, etc.). Many data used for the modeling approaches, both to define the constraints of the system and to validate the simulations (e.g. discharge and water quality data, piezometric level or data on urban and industrial waste water) are issued from the National Institute of Hydrology and Water Management - Bucharest,
HESSD

4, 2035-2071, 2007

Open-GIS decision aid system for the Bistrita River Basin

M. C. Trifu et al.

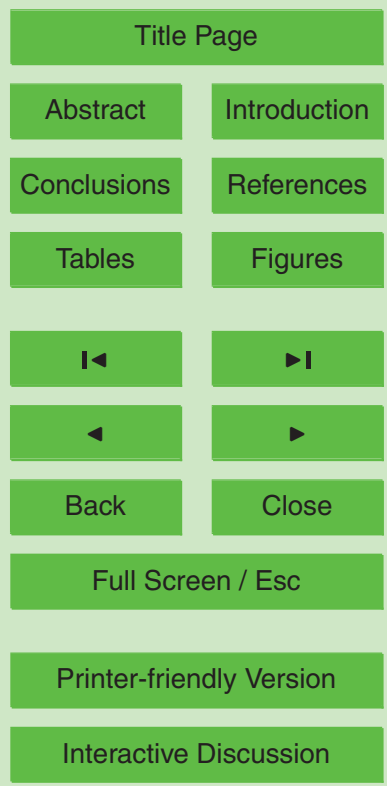

EGU 
the Siret Water Directorate - Bacau. The rainfall and snow data are provided by the National Administration of Meteorology - Bucharest.

Complementary data were obtained from our own surveys carried out, in the framework of Diminish Project, in the control sections of the main axis. In particular, the 5 determination of diffuse $\mathrm{P}, \mathrm{N}$ sources is based on the distribution of the land types into percentages of forests, pasture, agricultural and arable land (Corine Land Cover database) and our own measurements made in areas of different geological units and land-use types, in the upstream and middle part of the basin, upstream of the localities and industrial sites.

\section{Methods}

\subsection{The Diminish on-line system}

The DIMINISH on-line system is web-based with a distributed architecture, developed to improve the water quality management and the implementation of mitigation programs, in the Bistrita River Basin. Our system consists in a core server, which handles the interactions between the various modules, the end-users management, the display and manipulation of data. The main functions of the on-line system focus on the acquisition, storage, analysis, management and exchange of raster and vector graphic information and relate attribute data for the water quality management activities; in addition the information can be updated, data restored, thematic documents elaborated. At total value-added information is generated. The distribution of the spatial and tabular attribute data over an Internet Web-based network represents a powerful and effective communication method that overcomes the disadvantages of the classical approach. All the partners and end-users are able to access the system using a simple web browser (like Internet Explorer or Mozilla Firefox) to store, display, query, analyze and retrieve information. The system flow-chart is presented in Fig. 4.

Viewing GIS data on the Web, generally involves a three-tiered architecture:

HESSD

4, 2035-2071, 2007

Open-GIS decision aid system for the Bistrita River Basin

M. C. Trifu et al.

Title Page

Abstract

Introduction

Conclusions

Tables

References

Figures

14

$\rightarrow$

4

Back

Close

Full Screen / Esc

Printer-friendly Version

Interactive Discussion 
(1) the spatial server that can efficiently communicate with a Web server and is capable of sending and receiving requests for different types of data from a Web browser environment;

(2) the mapping file format that can be embedded into a Web page;

5 (3) the Web-based application in which maps can be viewed, download and queried by an end-user/client via a Web browser.

The proposed GIS approach allows to publish the data on the Web (webmapping) and offers the security of the existing data workflow, as well as information about how the data are created, maintained, and used by desktop applications. In this way the mapserver dynamically generates maps from the files stored in a certain folder every time a user sends a request, without changing the initial data files. The Diminish system allows to perform queries and make available different tools useful in order to i) process data for specific computations, ii) change the inputs for the mathematical models, iii) browse the mathematical models outputs in a GIS environment, iv) integrate the multi15 source processed information in order to better understand the impact of the pollution on humans and environment, v) upgrade the result in a Decision-Analysis common access space of the GIS Server, vi) provide the rightdecisions at both short and long term.

ArclMS (Internet Mapping Server) was chosen as core software for webmapping due to its ability to have simultaneous access to diverse data formats on the fly without conversion. The native formats can include those used by different commercial vendors. Other nonproprietary formats can be used as well, including the OGC standards for Geography Markup Language (GML), Web Map Server (WMS), Web Feature Server (WFS) and relational databases. The basic structure of ArclMS is presented in figure 5. The web interface was designed to obtain a simple and friendly environment for spatial data management and scenario creation, taking into account the end-user needs.

Open-GIS decision aid system for the Bistrita River Basin

M. C. Trifu et al.

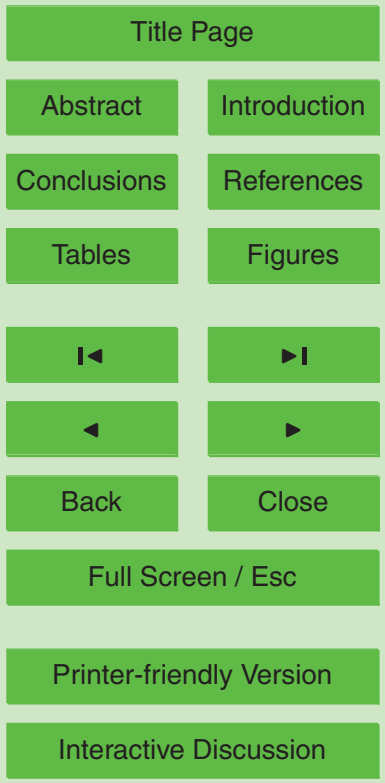


Riverstrahler is a model of nutrient transfer and biogeochemical functioning of hydrological networks at the scale of their watershed (Billen et al., 1994; Garnier et al, 1995). The model, mainly developed on the Seine river system (Billen and Garnier, 1999; Billen et al., 2001), has been applied to several European rivers, e.g. the Mosel (Garnier et al., 1999a, b), the Scheldt (Billen et al., 2004) and the Danube (Garnier et al., 2002; Trifu, 2002). Its essence lies on the coupling of a detailed model of biogeochemical processes (RIVE), and a hydrological model (HYDROSTRAHLER) describing the water flows through the watershed, using an original representation of the drainage network, partly based on the stream order classification of Strahler (1957). The RIVE model consists of 26 variables describing the physical-chemical and ecological state variables of the system. The kinetics of the processes relating these variables are all accessible to experimental determination. Their representation, as well as the value of the corresponding parameters are described in detail in Garnier et al. (1999a, b, 2002). In order to improve the capabilities of the Riverstrahler model, a GIS interface has been recently developed (Ruelland, 2004; Ruelland et al., 2007).

The model is based on the assumption of the unicity of the processes all over the aquatic continuum, i.e. the basic biogeochemical processes and their kinetics are assumed the same in all sectors of the drainage network, while the controlling factors such as the hydro-meteorological and morphological constraints, as well as the point and non-point sources of pollution explain the differences from a sector to another.

The complex network of tributaries of the Bistrita basin is described as nine subbasins, each represented by regular confluence scheme of rivers having the same mean morphological characteristics by stream-order, connected to the main branch of the Bistrita River (Fig. 6). The stagnant annexes, the reservoirs, are represented as well mixed reactors of idealized morphology, connected in parallel to branches.

Water flow through the drainage network structure is calculated from specific discharge for each sub-basin and branch by ten days periods. Hydrostrahler provides

Open-GIS decision aid system for the Bistrita River Basin

M. C. Trifu et al.

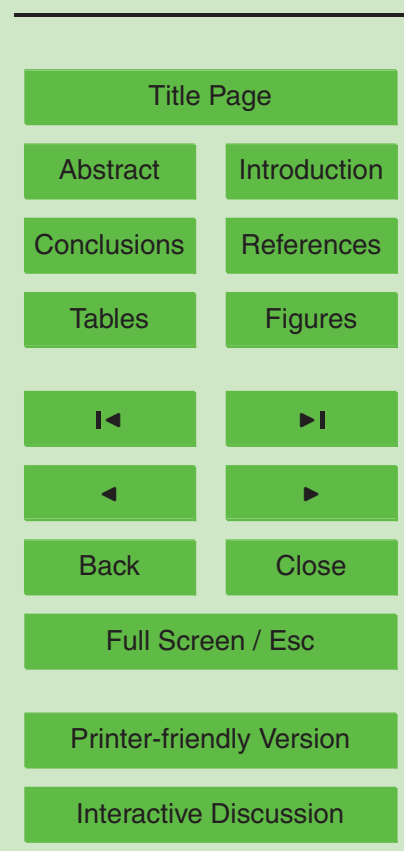

EGU 
two components of the discharge, namely surface flow and groundwater (base) flow. Diffuse sources of nutrients are taken into account by assigning a constant mean concentration of all state variables to these two components of the water fluxes. The concentrations in surface runoff and the composition of groundwater base flow were 5 obtained from own field campaigns.

For the sub-basins, the point sources are distributed by stream order, while for branches they are localized at their exact point of discharge.

\subsection{Modcou/Newsam model applied to the groundwater bodies of the Bistrita basin}

Groundwater modeling was realized for the alluvial aquifer situated in the south part of the Bistrita basin, using a coupled method which had the main characteristic to decompose the hydrological cycle into separate and independent phases, for which separated software modules are created.

The modeling software was made available by the specialists from the Centre de Geosciences de l'Ecole des Mines de Paris. The software has a modular structure: MODSUR is module for computation of hydrological balance, NEWSAM a module for groundwater flow modeling and pollutant transfer in sedimentary aquifers and MODCOU is devoted to a coupled modeling of surface and groundwater flows simultaneously (Ledoux et al., 1989, 2006). Taking into consideration the main geomorphological and climatic characteristics of the Bistrita basin, it was necessary to simulate also the snow melt effect, for which a new module, named FONTE, was developed.

The first step for the groundwater modeling approach was the data synthesis which leads to the elaboration of conceptual model of the studied aquifer. The required information was gathered from existing maps, scientific papers and other documents concerning the investigated Bistrita hydrographic basin. The limits of the modeled area are represented by the limits established for the groundwater body GWSI03, located in the Bistrita and its affluent water meadow and cliff. The total modeled area is about $600 \mathrm{~km}^{2}$, which a relatively large scale taking into accounts the importance of

HESSD

4, 2035-2071, 2007

Open-GIS decision aid system for the Bistrita River Basin

M. C. Trifu et al.

Title Page

Abstract

Introduction

Conclusions

Tables

References

Figures

14

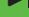

4

Back

Close

Full Screen / Esc

Printer-friendly Version

Interactive Discussion 
the groundwater for drinking water production. Unfortunately, it is the most exposed area to pollution caused by anthropogenic activity.

Taking into consideration the main hydrogeological characteristics (geological structure formed by alluvial deposits overlapping a large, uneven, clay layer; one unconfined

5 aquifer layer, with variable thickness from 5 to $15 \mathrm{~m}$; main slope of the piezometric surface around $3 \%$ and a total exploitable flow of approx. $68000 \mathrm{~m}^{3} /$ day) the aquifer was considered to be unconfined, heterogeneous, of variable depth. This aquifer is recharged by rainfall and it is in close relationship with the Bistrita river. The chosen conceptual model was a two-dimensional, single-layer model.

10 The input data to the groundwater model concerns: hydrological and climatic data (measured daily precipitations, evapotranspiration potential and temperature), wells data (measured exploited discharges from underground) and hydrogeological characteristic (transmissivity and storage coefficient).

Hydrological balance was modeled with MODSUR and the results provide calculated 15 flow values for each hydrological station within the basin, which are compared with calculated flows for the period 1994-2003.

Groundwater hydrodynamic regime was modeled with NEWSAM and the calibration was made by spatial distribution adjustment and value adjustment for transmissivities, so that the computed piezometric levels are similar to the measured values for the 20 period 1994-2003.

The calibrated hydrodynamic model for groundwater allowed a precise determination of main parameters that characterize the aquifer, which could be used in order to perform quantitative and qualitative analysis for water resources.

Regarding the pollutant transport, NEWSAM is capable to simulate convective trans25 port, so it can be used to simulate the nitrate transport within the aquifer; when traveling through the aquifer system, nitrate can be indeed considered as stable forms on a chemical and biochemical point of view.

The necessary data entry for simulating pollutant transport within the aquifer are the spatial extent of pollution source and the concentration of infiltrated solution, NEWSAM

HESSD

4, 2035-2071, 2007

Open-GIS decision aid system for the Bistrita River Basin

M. C. Trifu et al.

Title Page

Abstract

Conclusions

Tables

Figures

14

$\rightarrow 1$

4

Back

Close

Full Screen / Esc

Printer-friendly Version

Interactive Discussion 
being then capable to simulate the effect of point or diffuse pollution sources. The model outputs are nitrate concentrations within any aquifer cell which is concerned by the pollution plume.

HESSD

4, 2035-2071, 2007

\subsection{The cost-environment methodology}

5 Environmental costs methodology consists of the environmental damage costs of aquatic ecosystem degradation and depletion caused by a particular water use, such as the emission of pollutants (Wateco, 2002). The role of environmental costs in the context of selecting a cost-effective program of measures (Article 11 and Annex III of WFD) is to signal to what extent existing or new environmental standards are met or not and what are the associated costs, including environmental damage costs and any costs arising as a result of an inefficient allocation of water and pollution rights. Costs related to the improvement of water quality, implicitly a remediation cost, can be assimilated to an environmental cost. Any cost concerning the improvement of water quality until to reach the good status is an environmental one.

15 In the Diminish on-line system, the costs of measures for reaching the good status are related to two important types of measures, applied to the chemical pressures: i) costs for the urban and industrial sources, related to the wastewater treatment and sewage network; and ii) costs for reducing pollution from agriculture.

Concerning the point sources, the costs for applying the above mentioned measures 20 were established on the base of the available categories of sewage and wastewater works, for each human agglomeration, according to the Complementary Position Paper of Romania (Annex 3 of the Document European Integration Department - Ministry of Environment and Water Management, Romania). The economical approach is based on the knowledge of the costs of investments, of the operation and maintenance of 25 investments; these costs have been evaluated using unitary costs - Euro/population equivalent - obtained in Great Britain (Euroconsult EUROPEAID/114902/D/SV/RO) and taking into account the investment costs from ISPA projects.

Concerning the diffuse pollution from agriculture, the economical approach is based 2046

\section{Open-GIS decision} aid system for the Bistrita River Basin

M. C. Trifu et al.

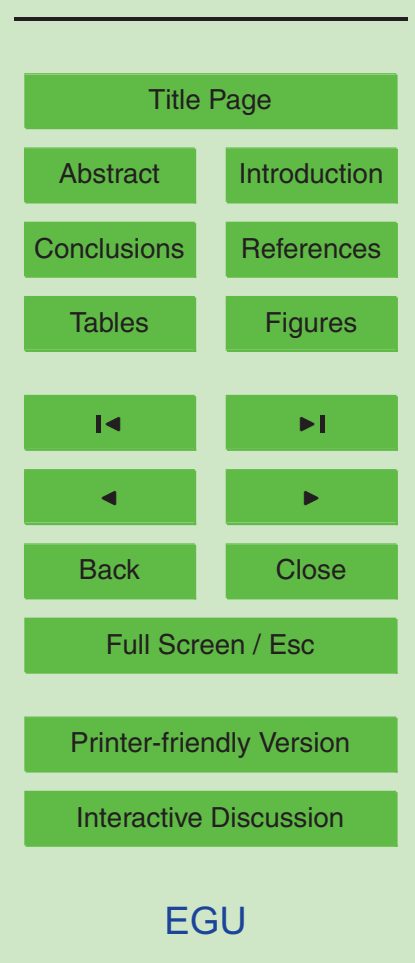


on the identification of the available measures for reduction of uncontrolled outflow of nitrogen compounds such as: reconversion of the arable areas into intensive grasslands; applying the good agricultural practice concerning composting the animal manure from farming and modifying the location of the manure; creation of natural wastewater treat5 ment in rural area (buffer areas). The corresponding costs have been evaluated on the basis of the french unitary cost and on the proportion of Gross Domestic Product (GDP) of agriculture between Romania and France.

Classification of measures is needed as a basis for the selection of cost-effective combinations of measures. The cost/effectiveness analysis has the role to identify the 10 most efficient measures from the cost/effect point of view. The effect of the measures is estimated by mathematical modeling like a difference between the nutrient loads simulated in both cases, before and after the implementation of the measure. The effect should be also analyzed on the basis of the user experience. The analyzed measure can be an individual measure or a combination of several individual measures. In both

cases, taking into account the cumulated measure cost and the reduction of nutrient quantity, a rapport between cost and efficiency raport is calculated (for each nutrient) for an automatically sort of the scenarios.

\section{Results}

\subsection{Seasonal changes in nutriments concentrations}

20 In order to analyze the effect of human activities on the surface water quality, we have selected a large area of the Bistrita basin (Fig. 6) situated in the upstream and middle part of the basin, in front of the groundwater body GWSI03, divided into 8 sub-basins and a main axis of the Bistrita River. This area is dominated by livestock and forests and characterized by the main sources of point source pollution $(70 \%$ of the urban and industrial sources). The input-output of the Riverstrahler model have been integrated into the Diminish system allowing a visualization of the nutrient evolution at the basin
HESSD

4, 2035-2071, 2007

Open-GIS decision aid system for the Bistrita River Basin

M. C. Trifu et al.

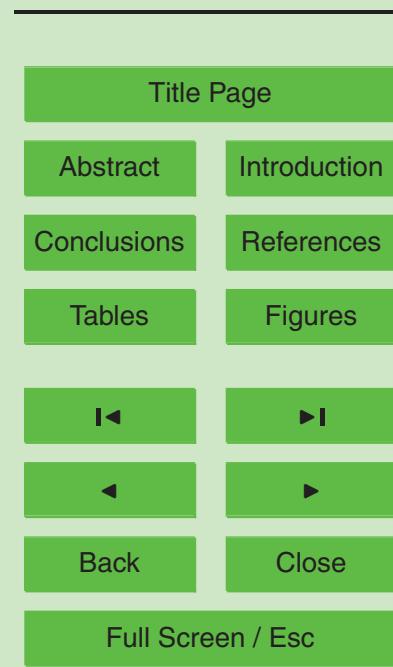

Printer-friendly Version

Interactive Discussion 
outlets and at every $\mathrm{km}$ along the main axis of the analyzed area. The simulations have been done for two years, a dry year in 2000 and a wet year in 2002. An example is given for the discharge, nutrients and oxygen concentrations, for the year 2000 at the outlet of the Bistricioara river basin and on the main axis (Barnar control station), 5 (Fig. 7). The model adequately simulates the level and the variations of the variables.

Concerning the basin response to the changing pressures within the river catchments, we have computed the nutrient budgets at the outlet of the selected area. The data shows the decrease of nitrogen and phosphorus fluxes due to the reduction of industrial sources after several economical units were closed within the basin (Fig. 8).

\subsection{Measures for reducing nutriments}

\subsubsection{Surface water}

Each of the scenarios created using the DIMINISH on-line system represents in fact a series of measures, taken into account to improve the water quality. In the framework of the Diminish system the quantification of the effect of the measures is based on the use of the mathematical modeling tools which help for a proper analysis of the pollution transport. In this perspective, we have used the Riverstrahler model to explore the effect of point and diffuse sources on the budget of nitrogen and phosphorus obtained at the end of the river catchments.

\section{a) Decreasing the point sources}

The discharge of nutrients into water bodies may exacerbate the problem of eutrophication, particularly in the lower stretches of the river system. For this reason we have chosen as a reference scenario the situation of the dry year 2000. The tested scenario corresponds to the 2015 prospective scenario established in the scope of the implementation of the Water Framework Directive. It considers the same hydrology as in 2000 and point sources corresponding to the implementation of the national and Eu-
HESSD

4, 2035-2071, 2007

Open-GIS decision aid system for the Bistrita River Basin

M. C. Trifu et al.

Title Page

Abstract

Introduction

Conclusions

Tables

References

Figures

14

$\rightarrow$

4

Back

Close

Full Screen / Esc

Printer-friendly Version

Interactive Discussion 
ropean legislation, such as the Directive 91/271/EEC, including the generalization of use of advanced tertiary treatment technology from urban effluents in cities $>10000$ inhabit.-equiv. Diffuse sources were calculated from the land use of the year 2000.

Considering the Romanian conformation period to the European regulations and the 5 estimated connection trends of population to the sewage system and to the wastewater treatment plants -as mentioned in the Romanian Complementary Position Document, Annex 3, in 2015 year, in the analyzed area of Bistrita basin- only four agglomerations will have $100 \%$ of the population connected to the wastewater treatment plants. The evolution of the inhabitant-equivalents has been provided by the National Institute of 10 Statistics of Bucharest. The information concerning the functioning of actual treatment technology within the Waste Water Treatment Plant (WWTP) was provided by the Siret Water Directorate of Bacau. For two of the agglomerations, characterized by more than 10000 inhabit.-equiv., the prospective scenario assumes the construction of a new tertiary step and an improvement of existing treatment, as well as the extension

of the sewerage network (Table 1). For the other two agglomerations, with less than 10000 inhabit.-equiv., we have taken into consideration the improvement of biological treatment and the extension of sewerage network.

The response of the model to a reduction of point sources of nutrients for the hydrological conditions of the year 2000 is given in Fig. 9. The values show a decrease in nutrient loads of almost $6 \%$ for nitrogen and $17 \%$ for phosphorus.

The cost of the above measures (investment) was computed on the basis of values communicated by the National Administration "Apele Romane". In order to calculate the cost of the elected measures, we have used the Gross Value Added for adapting the European unitary costs to the Romania level. The investment costs are based on unitary costs for each inhabitant equivalent (euro/inhabit.-equiv.) for sewage network (e.g. rehabilitation/improvement/extension) and for wastewater treatment plants (e.g. rehabilitation/improvement/extension), (Table 2). Based on the estimated trends of connection of the population- equivalent to the sewage and wastewater treatment plants, we have estimated the costs of the water quality improvement for each agglom-
HESSD

4, 2035-2071, 2007

Open-GIS decision aid system for the Bistrita River Basin

M. C. Trifu et al.

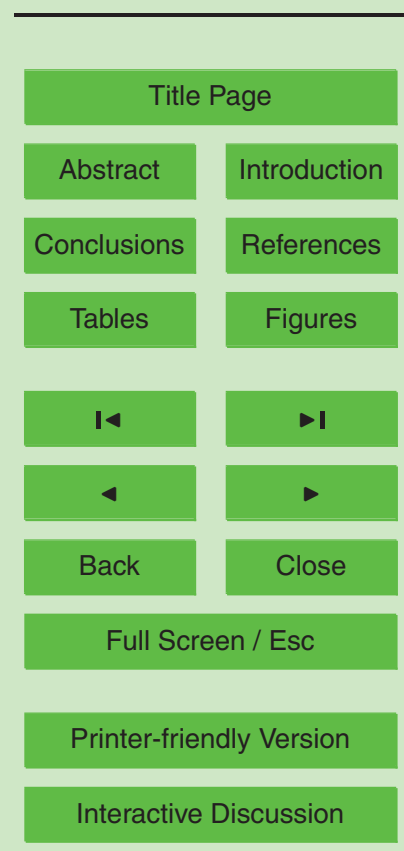

EGU 
eration: this estimated cost is 16.229 .806 euros for reducing the point sources.

b) Decreasing the diffuse sources

HESSD

Another possible measure for reducing the nutrients transferred by the surface water can be the changes of land use, e.g. the conversion of selected agricultural land into 5 extensively used grassland or, land use based on the principles of organic farming (reduction of overall fertilizer requirements). The tested scenario was designed taking into account the rate and the pattern of agricultural development that was forecasted based on agricultural indexes (e.g. the evolution of the Gross Value Added GVA in the North East regional development area which includes the Bistrita River Basin).

10 This economical analysis of the production evolution shows an increase of the GVA in agriculture during the next period.

The tested scenario corresponds to the change of the land-use data, by increasing, within the selected river catchments in the upstream part of the basin, the pasture surface (an increase of pasture of $1587 \mathrm{ha}$ ) to the detriment of cropping area, (e.g. Neagra

15 Sarului basin, Fig. 10). Point and diffuse sources were computed from the database of the year 2000. For the rest of the land use, we have kept the data of the Corinne Land Cover data base, the other constraints of the reference scenario, corresponding to the situation of the year 2000 (hydro-meteorology, point sources).

The results of the model show a decrease of nutrient concentrations, at the outlet of the basin, of almost $3 \%$ for nitrogen and $41 \%$ for phosphorus (Fig. 11). To evaluate the cost of this measure, we have used an estimated cost per hectare and per year, communicated by the National Administration "Apele Romane", which does not take into account the social effect (e.g. the conversion of agricultural land affects the market balance, since it means that land is taken out of production and replaced by extensively used grassland). This cost was adapted taking into account unitary costs from the Rhine-Meuse River Basin (http://www.eau2015-rhin-meuse.fr/services) considering the proportion of GDP of agriculture between Romania and France. With a unitary cost amounting 77 Euros/ha for this measure, the estimated cost of the tested

Open-GIS decision aid system for the Bistrita River Basin

M. C. Trifu et al.

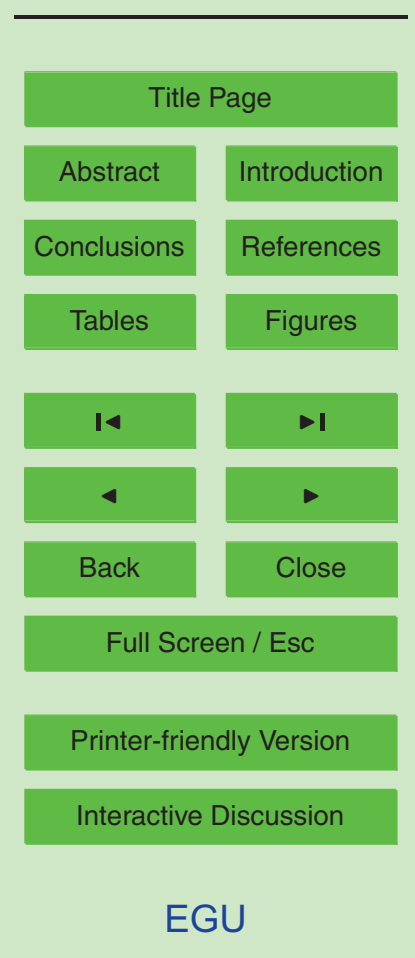


measure equals about 122000 euros for the whole surface area.

The prioritization of the measures to be taken and the selection of a set of measures is evaluated from the cost effectiveness ratio. The Diminish system allows a cost/efficiency analysis for the possible measures on the basis of the ratio between 5 measures cost and the decrease of pollution given the actual situation (the quantity of nutrients that will be reduced). The ratio is expressed by Euro per $\mathrm{kg}$ of load reduction.

Our results show that, for the analyzed cases, the most efficient measure able to reduce the nutrients in surface waters, at the river catchments scale, is the reduction of diffuse sources.

\subsubsection{Groundwater}

The Diminish system also permits a quantification of the effect of the measures that could be implemented for reducing nitrate concentrations within the aquifer area, by using the NEWSAM capability to simulate the pollutant transport and to calculate nitrate concentrations in each cell of the aquifer grid.

The reduction of nitrate concentration within the aquifer is necessary to maintain a good status of the groundwater bodies, which is used for drinking water supply.

Pollution sources of groundwater can originate from point sources (leakage from manure storage points) or from diffuse sources (intensive fertilizer use, effect of land use type).

20 In order to illustrate the Diminish system functioning, a simulation of some measures effect was made at a local scale, exploring mainly the effect of a diffuse source reduction.

In this perspective, we simulated the effect of a culture shift and land use modification for the same arable area (about $25 \mathrm{ha}$ ), in order to find the most costless measure that 25 could be implemented.

In a reference scenario, we simulate the effect of fertilizer use on the nitrate concentrations within the aquifer. The arable area was supposed to be cultivated with corn, and the quantities of chemical fertilizers used in the scenario $(27.5 \mathrm{~kg} \mathrm{~N} / \mathrm{ton}$ of
HESSD

4, 2035-2071, 2007

Open-GIS decision aid system for the Bistrita River Basin

M. C. Trifu et al.

Title Page

Abstract Introduction

Conclusions

Tables References

Figures

14

Back

Close

Full Screen / Esc

Printer-friendly Version

Interactive Discussion 
corn production) were compatible with the requirements given by the Good Agricultural Practices Code implemented within the EU WFD.

The model response for this scenario, is represented by the spatial extension of the pollutant plume (about $1400 \mathrm{ha}$ ) and the concentrations of nitrate, which vary between

55 and $17 \mathrm{mg} / \mathrm{l}$ (see Fig. 12). The fertilizer costs calculated here by the Diminish system are about 776 euros/year (representing the fertilizers cost for a total corn production obtained from the area of $25 \mathrm{ha}$ ).

In order to reduce these concentrations we simulate a rotation culture scenario, by replacing the corn culture with a culture of potatoes, which does needs as much fertil10 izers as the corn culture ( $5.3 \mathrm{~kg} \mathrm{~N} /$ ton of potatoes production)

The effect was a decrease of nitrate concentrations from a maximal value of $17 \mathrm{mg} / \mathrm{l}$ (dark grey squares in Fig. 12) to a maximal value of $6 \mathrm{mg} / \mathrm{l}$ (medium grey in Fig. 13), which means a reduction of almost $65 \%$. In the same time the extensions of polluted area decreases, from 1400 ha to 750 ha (see Figs. 12 and 13). The fertilizer costs for this "potatoes" scenario are about 96 euros/year (compared to 776 euros/year for the "corn" scenario).

A reduction in nitrate concentrations reduction could also be obtained by implementing an other land use change measure, for example by substituting this 25 ha arable area cultivated with corn by a 25 ha intensive pasture area (source nitrates concentra20 tion about $4 \mathrm{mg} / \mathrm{l})$. For this third scenario, the response of the model put in evidence that nitrate concentrations within the aquifer studied reached a maximal value of about $10 \mathrm{mg} / \mathrm{l}$. The measure cost for this scenario was evaluated by the Diminish system at about 1925 euros/year (77 Euro/ha/year, according to unitary costs identified in France and taking into consideration the different values of IPB for Romanian agriculture).

25 As a whole, it is obviously less expensive and most efficient to select the measure involving a shift of cultures than to implement a land use change.
HESSD

4, 2035-2071, 2007

\section{Open-GIS decision} aid system for the Bistrita River Basin

M. C. Trifu et al.

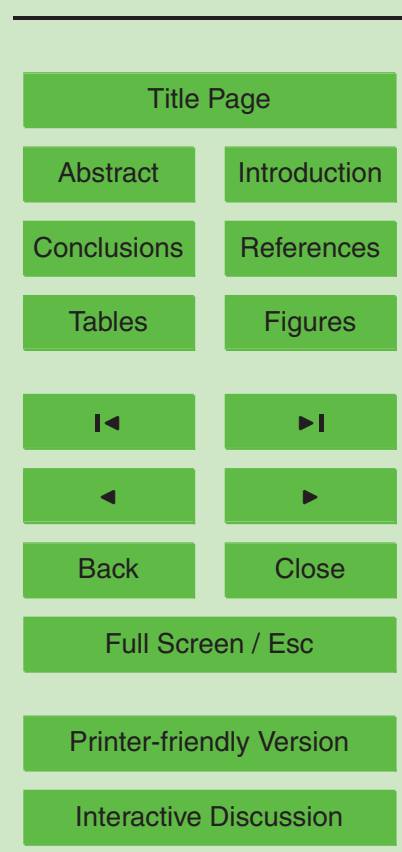

EGU 


\section{Conclusions}

Our GIS system, focusing on nutrient management in the Bistrita river basin, is the first reported GIS on-line system which integrates a hydrological, geological, environmental and economical data base, by using an open web-based interrogation and analysis 5 informatics tool, such that the basin management evaluation are made available to remote users.

The relationship between the pressure change and the economic consequences is largely facilitated using such a GIS database and mathematical modeling, both being included in the Diminish system. An evaluation of human impact using GIS tools and modeling approaches represents a new -and perhaps difficult- experience for the water end-users, but the Diminish system provides however a friendly and easy to use interface able to take up this challenge. Water quality analysis needs to make use and to integrate many sources of information. Web driven Open GIS technologies represent an adequate environment to integrate and manage such information, providing 5 right tools for data manipulation, analysis and visualization. Diminish on-line system is using OGC (Open Geospatial Consortium) and WC3 (World Wide Web Consortium) standard compliant tools meeting the new recommendations of the INSPIRE directive.

The study has proved that outputs of the developed system can be used for the assessment of ecological cause/effect relationships and ultimately for the selection of measures. By discharging nutrient loads from a sewage treatment plant into a water course, it is well known that high biological oxygen demand, total nitrogen and phosphorus loads may adversely affect the aquatic system. Hence, for the selected cases, great efforts must be placed on the sewage treatment plant to quickly comply with the requirements stipulated by the Waste Water Ordinance. Nutrient budget calculations 25 and cost - effectiveness analysis have shown that the measures in the field of "upgrading the wastewater treatment plant" tend to be more cost intensive than measures that aimed at reducing nutrients from agriculture. Measures dedicated to reduce point source pollution could be generally supplemented by improving the structural quality of
HESSD

4, 2035-2071, 2007

Open-GIS decision aid system for the Bistrita River Basin

M. C. Trifu et al.

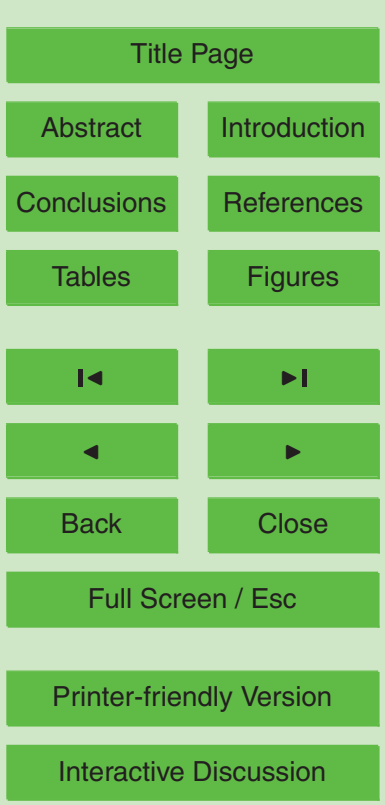

EGU 
the hydrosystem, e.g. the creation of wetlands to reduce diffuse sources, which could increase with additional agriculture needs.

However, land should only be converted if a benefit is produced for the environment. There are examples of agricultural systems, deserving the nature conservation, largely 5 based on arable crop production but with a minimal use of fertilizers. In some areas, the conversion of agricultural land into extensive pasture could have harmful impacts (Volkswirt et al., 2004), and better measures to be taken are to ensure the continuation of varied crop rotation systems, minimal fertilizers application, and continuous agricultural use. In order to select the correct measures in individual landscape systems, an 10 inventory of any region requirements must be carried out before using an integrated, GIS based, support system.

Analysis and assessment of the most efficient combinations of measures constitute a basic step for the preparation of management programs for any river basin district, as part of the River Basin Management Plans. In this respect the nutrient trend within

a basin, as it can be simulated and forecasted by the Diminish GIS system help to elaborate an argumentation guide for decision-makers.

Acknowledgements. This work was carried out within the program Life Environment, in the framework of the Diminish Project (LIFE03 ENV/ RO/000539), co-financed by the European Commission. Thanks are due to the Siret Water Directorate - Bacau for providing part of 20 the input data of the models and the validation data. The authors wish to thank P. Serban from National Administration "Apele Romane" for useful discussions and support in the project implementation.

\section{References}

Agence de l'Eau Rhin - Meuse: Elaboration du programme des mesures dans le basin RhinMeuse. Section: Agriculture, http://www.eau2015-rhin-meuse.fr/services, 2005.

Billen G., Garnier, J, and Hanset, P.: Modelling phytoplankton development in whole drainage network: the RIVERSTRAHLER Model applied to the Seine river system, Hydrobiologia, 289, 119-137, 1994.
HESSD

4, 2035-2071, 2007

Open-GIS decision aid system for the Bistrita River Basin

M. C. Trifu et al.

Title Page

Abstract

Introduction

Conclusions

Tables

References

Figures

14

$\rightarrow$

4

Back

Close

Full Screen / Esc

Printer-friendly Version

Interactive Discussion 
Billen, G. and Garnier, J.: Nitrogen transfers through the Seine drainage network: a budget based on the application of the Riverstrahler model, Hydrobiologia, 410, 139-150, 1999

Billen, G., Garnier, J., Deligne, C., and Billen, C.: Estimates of early-industrial inputs of nutrients to river systems : implication for coastal eutrophication, Sci. Total Environ., 243/244, 43-52, $5 \quad 1999$

Billen G., Garnier, J., Ficht, A., and Cun, C.: Modeling the response of water quality in the Seine river estuary to human activity in its watershed over the last 50 years, Estuaries, 24(6B), 977-993, 2001.

Billen, G., Garnier, J., and Rousseau, V.: Nutrient fluxes and water quality in the drainage network of the Scheldt basin over the last 50 years, Hydrobiologia, 50, 47-67, 2004

Garnier J., Billen, G., and Coste, M.: Seasonal succession of diatoms and chlorophyceae in the drainage network of the Seine river: observations and modeling, Limnol. Oceanogr., 40, 750-765, 1995.

Garnier, J., Billen, G., and Palfner, L.: Understanding the oxygen budget of the Mosel drainage 15 network with the concept of heterotrophic/autotrophic sequences: the Riverstrahler approach, Hydrobiologia, 410, 151-166, 1999a.

Garnier, J., Leporcq, B., Sanchez, N., and Philippon, X.: Biogeochemical budgets in three large reservoirs of the Seine basin (Marne, Seine and Aube reservoirs), Biogeochemistry, 47, 119-146, 1999b

20 Garnier, J., Billen, G., Hannon, E., Fonbonne, S., Videnina, Y., and Soulie, M.: Modeling transfer and retention of nutrients in the drainage network of the Danube river, Estuar. Coast. Shelf Sci., 54, 285-308, 2002.

Ledoux, E., Girard, G., de Marsily, G., Villeneuve, J. P., and Deschenes, J.: Spatially distributed modeling: Conceptual approach, coupling surface water and groundwater. In: Morel-Seytoux $\mathrm{H}$ J, editor. Unsaturated Flow in Hydrologic modeling - Theory and Practice. NATO ASI Ser. C, volume 275. Kluwer Academic, Norwell, Massachussett, 435454, 1989,.

Ledoux, E., Gomez, E., Monget, J. M., et al.: Agriculture and groundwater nitrate contamination in the Seine basin. The STICS-MODCOU modelling chain, Sci. Total Environ., doi:10.1016/j.scitotenv.2006.12.002, 2006

30 Ruelland D.: SENEQUE, logiciel SIG de modélisation prospective de la qualité de l'eau. Paris : Hermès, Revue Internationale de Géomatique, 14, 97-117, 2004.

Ruelland, D., Billen, G., Brunstein, D., and Garnier, J.: SENEQUE: a multi-scaled GIS interface to the RIVERSTRAHLER model of the biogeochemical functioning of river systems, Sci. Total

HESSD

4, 2035-2071, 2007

Open-GIS decision aid system for the Bistrita River Basin

M. C. Trifu et al.

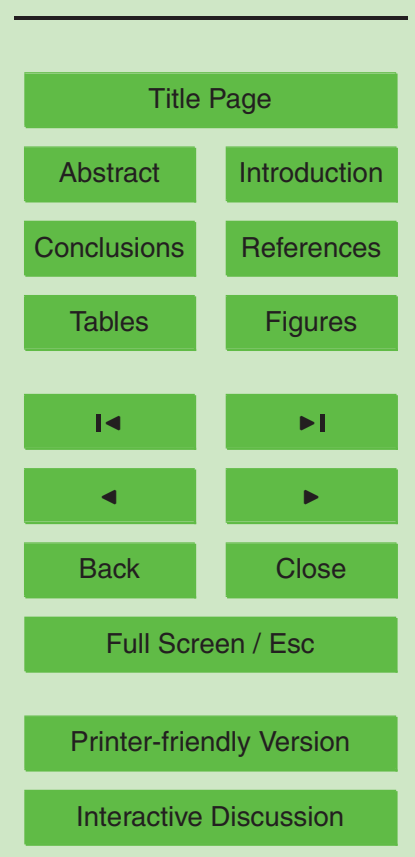

EGU 
Environ., 375, 257-273, 2007.

Strahler, A.-N.: Quantitative analysis of watershed geomorphology, Washington, Geophys. Union Trans., 38, 913-920, 1957.

Trifu, M. C.: Transfert des nutriments dans le basin du Danube et les apports a la Mer Noire. Thèse Université Paris 6, Paris (France), p. 145, 2002

Trifu, M. C., Garnier, J., Billen, G., and Drobot, R.: Modelling retention of nutrients and ecological impact in the Danube Basin. Limnological Reports. Proceedings of the 34th Conference, 34, 87-94, 2002

Volkswirt, E. I., Kraemer, A., Kranz, N., Gorlich, B., Dwork, Th., Borchardt, D., Richter, S., and Willecke, J.: Basic principles for selecting the most cost-effective combinations of measures for inclusion in the programme of measures as described in Article 11 of the Water Framework Directive. Environmental Research of the Federal Ministry of the environment, nature conservation and nuclear safety, Research Report 20221210 UBA-FB000563/E, Berlin, 2004.

15 Wateco (European Water Economics Working Group): Economics and the Environment. The implementation challenge of the Water Framework Directive, EU Rapport, 2002
HESSD

4, 2035-2071, 2007

Open-GIS decision aid system for the Bistrita River Basin

M. C. Trifu et al.

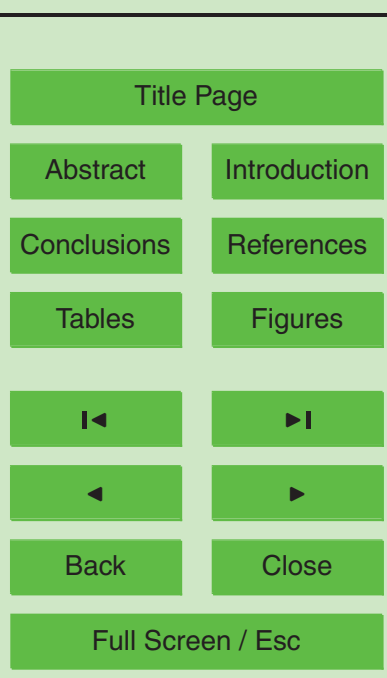

Printer-friendly Version

Interactive Discussion 


\section{HESSD}

4, 2035-2071, 2007

\section{Open-GIS decision} aid system for the Bistrita River Basin

M. C. Trifu et al. scenario (2000 year) and the prospective scenario (2015 year).

\begin{tabular}{|c|c|c|c|c|c|c|}
\hline \multirow[b]{2}{*}{$\begin{array}{l}\text { Human agglom- } \\
\text { eration }\end{array}$} & \multicolumn{3}{|c|}{2000 year } & \multicolumn{3}{|r|}{2015 year } \\
\hline & $\begin{array}{l}\text { Inhabit. } \\
\text { equiv. }\end{array}$ & $\begin{array}{l}\text { Sewerage } \\
\text { network } \\
(\mathrm{km})\end{array}$ & $\begin{array}{l}\text { Type of } \\
\text { WWTP }\end{array}$ & $\begin{array}{l}\text { Inhabit. } \\
\text { equiv. }\end{array}$ & $\begin{array}{l}\text { Sewerage } \\
\text { network } \\
(\mathrm{km})\end{array}$ & $\begin{array}{l}\text { Type of WWTP } \\
\text { (necessary actions) }\end{array}$ \\
\hline Piatra-Neamt & 131796 & 61 & $\begin{array}{l}\text { mecanical } \\
\text { biological }\end{array}$ & 128726 & 127 & $\begin{array}{l}\text { New tertiary step and improve- } \\
\text { ment }\end{array}$ \\
\hline Vatra-Dornei & 17168 & 32 & $\begin{array}{l}\text { mecanical } \\
\text { biological }\end{array}$ & 17037 & 79 & $\begin{array}{l}\text { New tertiary step and improve- } \\
\text { ment }\end{array}$ \\
\hline Bicaz & 8446 & 15 & $\begin{array}{l}\text { mecanical } \\
\text { biological }\end{array}$ & 8026 & 37 & $\begin{array}{l}\text { Improvement biological waste } \\
\text { water treatment plant }\end{array}$ \\
\hline Brosteni & 6603 & 0 & $\begin{array}{l}\text { mecanical } \\
\text { biological }\end{array}$ & 6509 & 65 & $\begin{array}{l}\text { Improvement biological waste } \\
\text { water treatment plant }\end{array}$ \\
\hline
\end{tabular}




\section{HESSD}

4, 2035-2071, 2007

\section{Open-GIS decision aid system for the Bistrita River Basin}

M. C. Trifu et al. Inv (Euro/inh.eq.) Untitary costs for investments

\begin{tabular}{|c|c|c|c|}
\hline & Localities & Necessary works & $\begin{array}{l}\text { Untitary costs for investments } \\
\text { Inv (Euro/inh.eq.) }\end{array}$ \\
\hline \multirow{5}{*}{ Sewerage } & \multirow{2}{*}{$<10000$ inh.eq. Rural area } & Extension & 75 \\
\hline & & Rehabilitation/Improvement & 40 \\
\hline & \multirow{3}{*}{ >10000 inh.eq. Urban area } & Extension & 160 \\
\hline & & Rehabilitation/Improvement & 60 \\
\hline & & New Tertiary step & $I_{n v}=837.21^{*}$ (inh.eq.) ${ }^{-0.2318}$ \\
\hline \multirow[t]{5}{*}{ Waste water treatment plant } & \multirow[t]{5}{*}{ >2000 inh.eq. } & $\begin{array}{l}\text { New tertiary step and im- } \\
\text { provement }\end{array}$ & $I_{n v=} 1395.35^{\star}$ (inh.eq.) -0.2318 \\
\hline & & $\begin{array}{l}\text { Conventional waste water } \\
\text { treatment plant }\end{array}$ & $I_{n v}=1953.49 *$ (inh.eq.) ${ }^{-0.2318}$ \\
\hline & & $\begin{array}{l}\text { Conventional waste water } \\
\text { treatment plant plus New } \\
\text { tertiary step }\end{array}$ & $I_{n v}=2790.71^{*}$ (inh.eq.) ${ }^{-0.2318}$ \\
\hline & & $\begin{array}{l}\text { New waste water treatment } \\
\text { conventional biological step } \\
\text { in improvement the mechan- } \\
\text { ical step }\end{array}$ & $I_{n v}=976.74^{\star}$ (inh.eq.) ${ }^{-0.2318}$ \\
\hline & & $\begin{array}{l}\text { Improvement biological waste } \\
\text { water treatment plant }\end{array}$ & $\mathrm{I}_{n v}=488.37^{\star}$ (inh.eq.) ${ }^{-0.2318}$ \\
\hline
\end{tabular}

Table 2. The unitary investment costs necessary for the achievement of sewerage network and waste water treatment plants.
Title Page

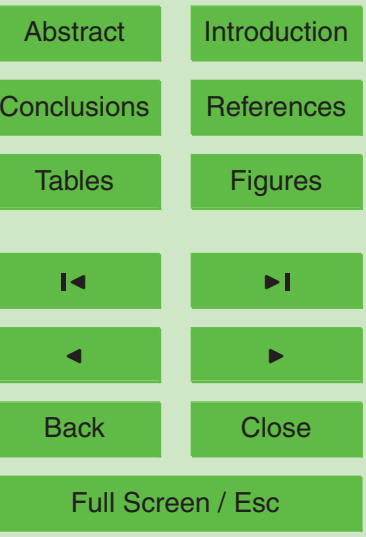

Printer-friendly Version

Interactive Discussion 
HESSD

4, 2035-2071, 2007

Open-GIS decision aid system for the Bistrita River Basin

M. C. Trifu et al.

\section{Title Page}

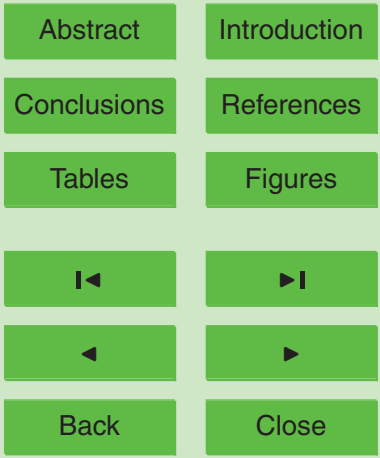

Full Screen / Esc

Printer-friendly Version

Interactive Discussion 


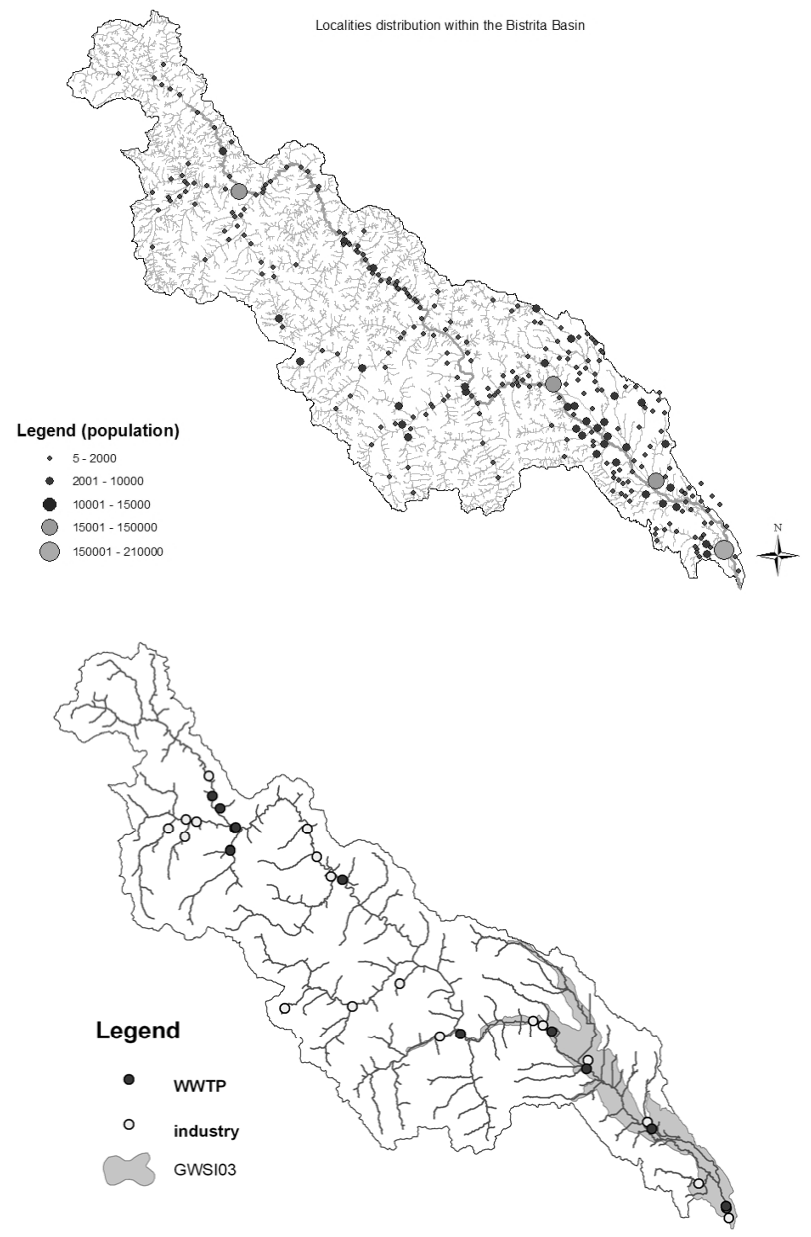

HESSD

4, 2035-2071, 2007

Open-GIS decision aid system for the Bistrita River Basin

M. C. Trifu et al.

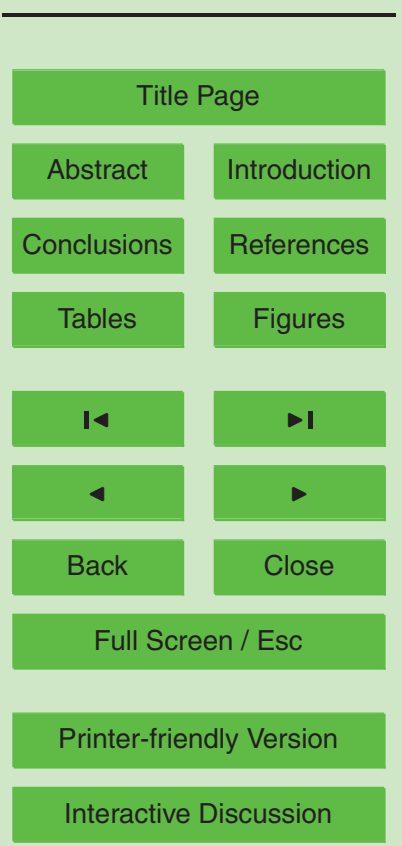

Fig. 2. Localities distribution and the point sources and the groundwater body within the Bistrita River Basin. 


\section{HESSD}

4, 2035-2071, 2007

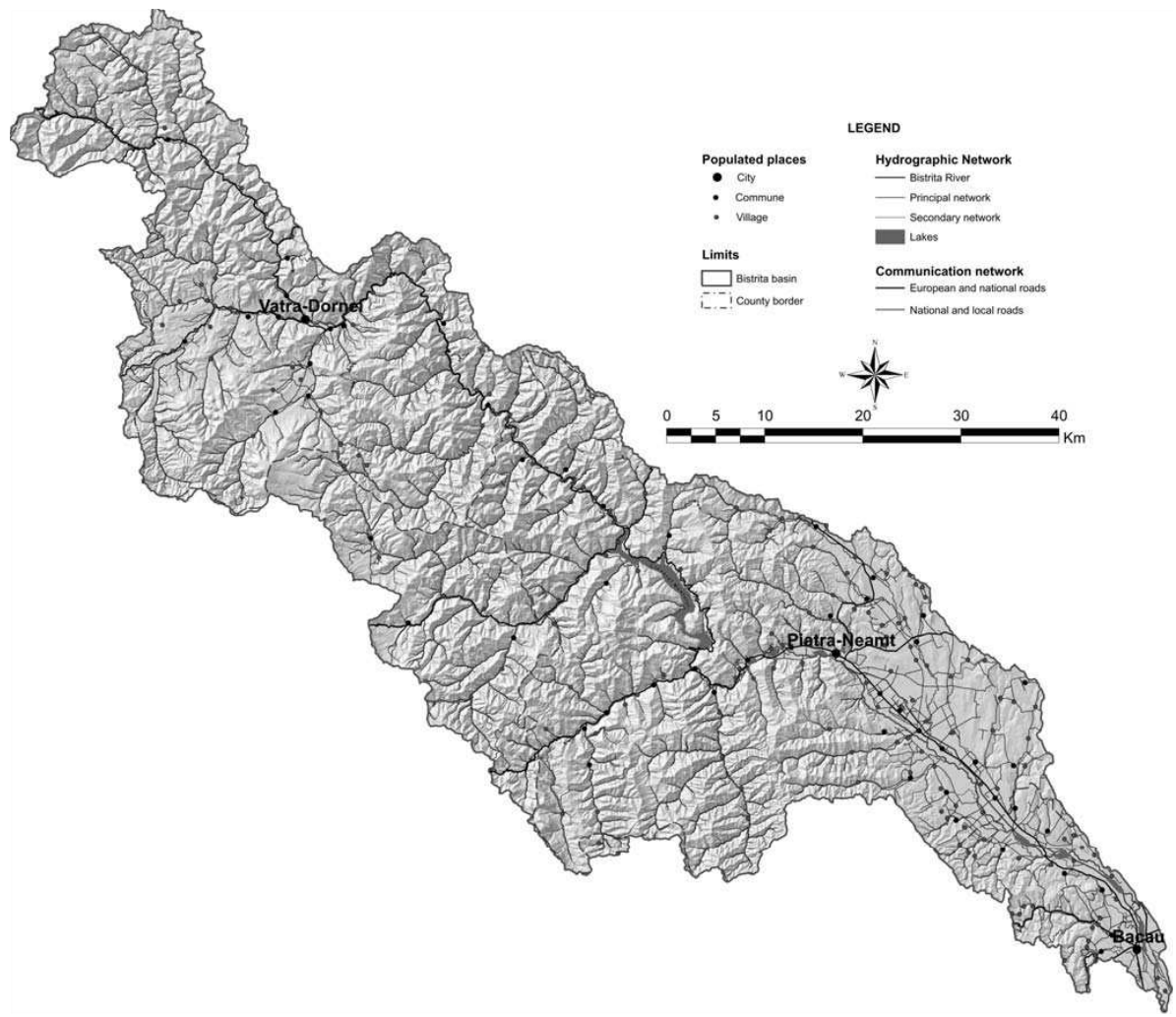

Open-GIS decision aid system for the Bistrita River Basin

M. C. Trifu et al.

Title Page

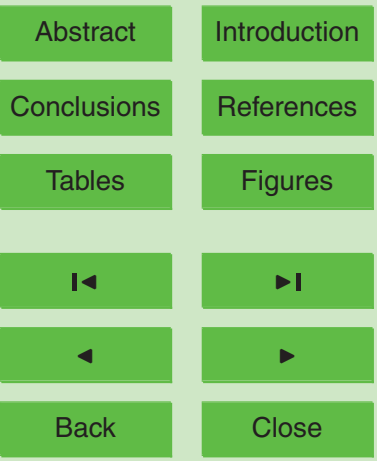

Full Screen / Esc

Printer-friendly Version

Interactive Discussion 


\section{HESSD}

4, 2035-2071, 2007

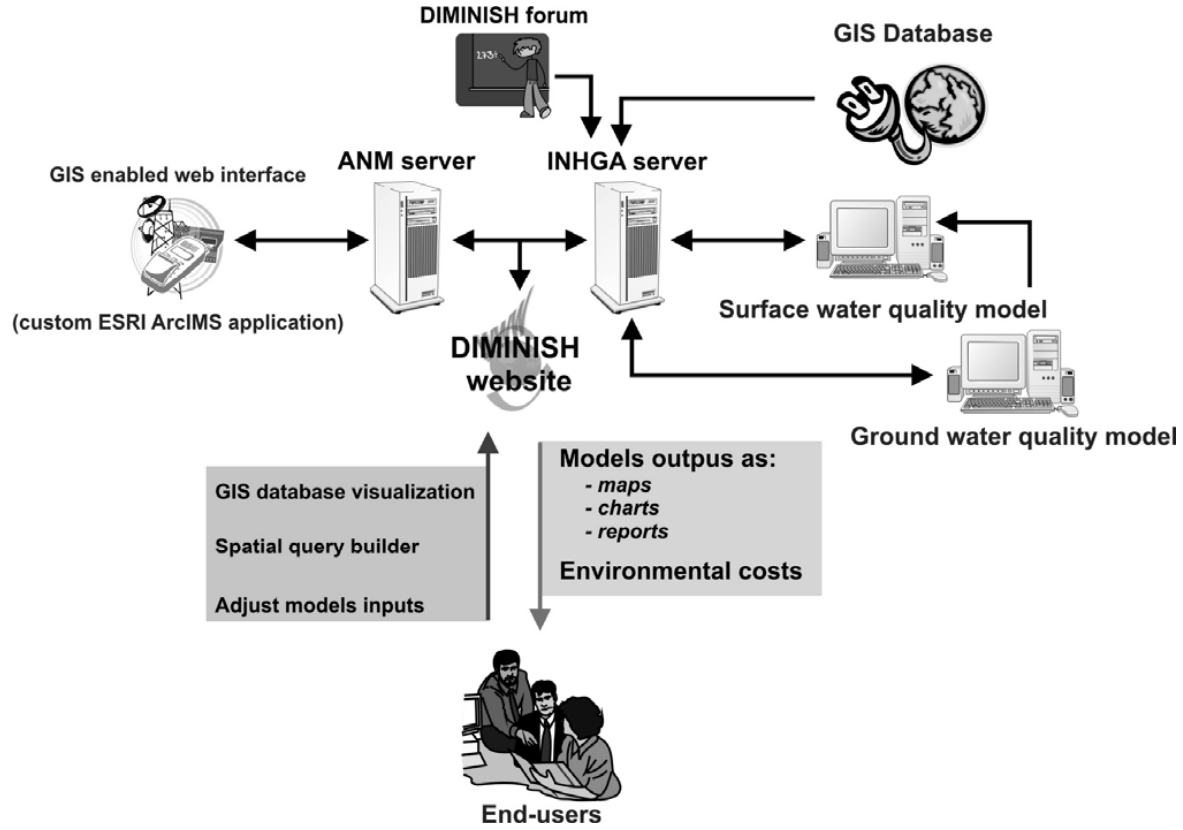

Open-GIS decision aid system for the Bistrita River Basin

M. C. Trifu et al.

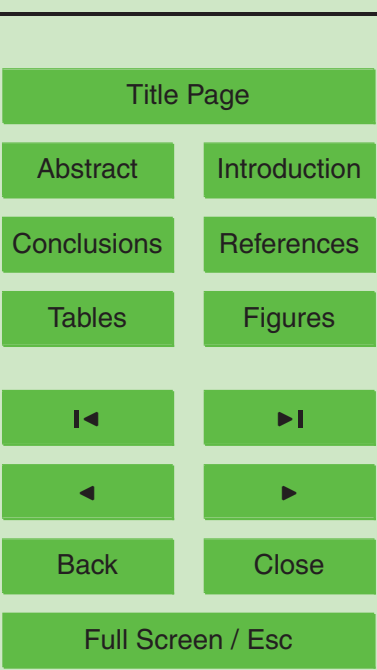

Printer-friendly Version

Interactive Discussion 


\section{HESSD}

4, 2035-2071, 2007

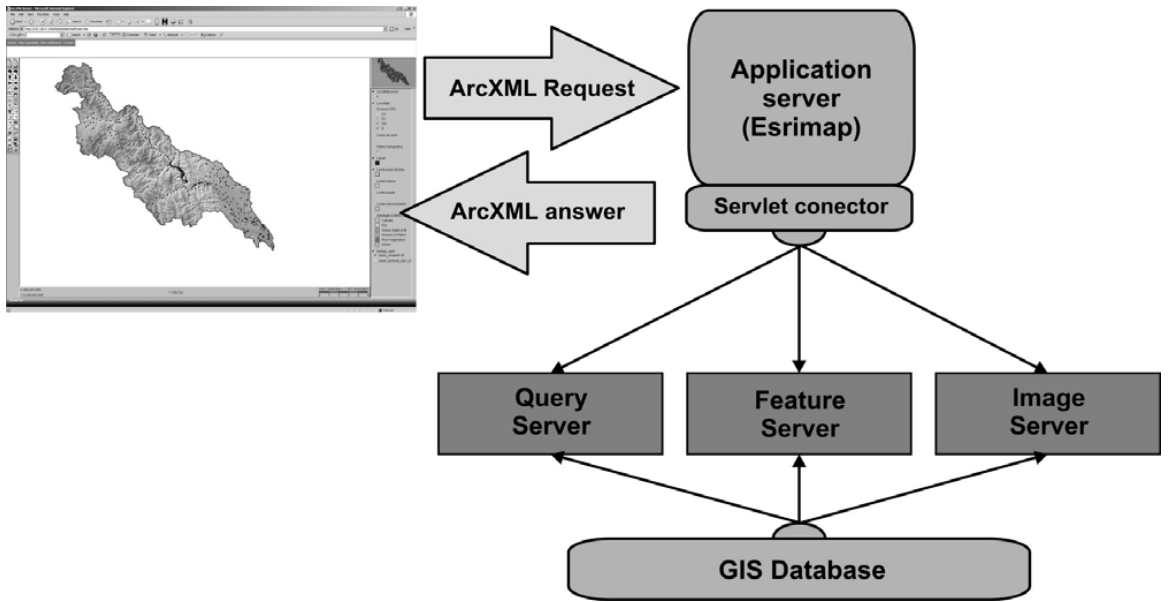

Open-GIS decision aid system for the Bistrita River Basin

M. C. Trifu et al.

Title Page

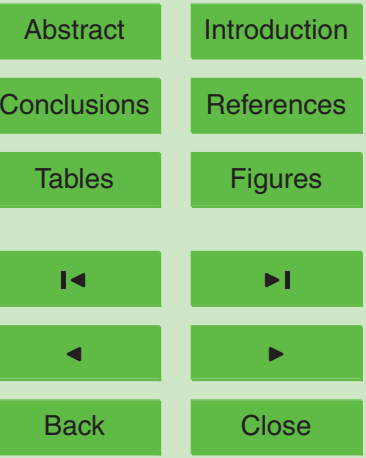

Full Screen / Esc

Printer-friendly Version

Interactive Discussion 


\section{HESSD}

4, 2035-2071, 2007

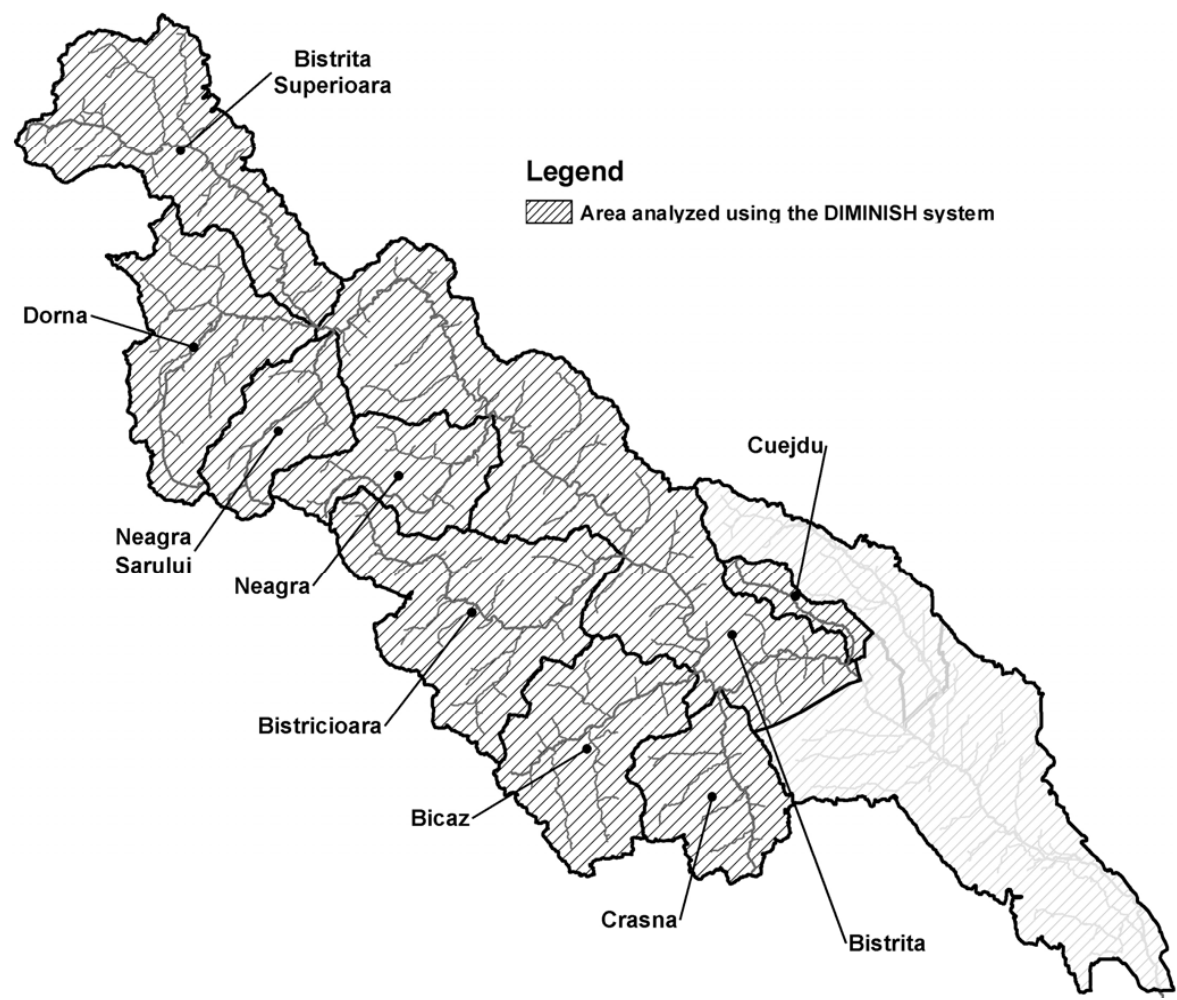

Open-GIS decision aid system for the Bistrita River Basin

M. C. Trifu et al.

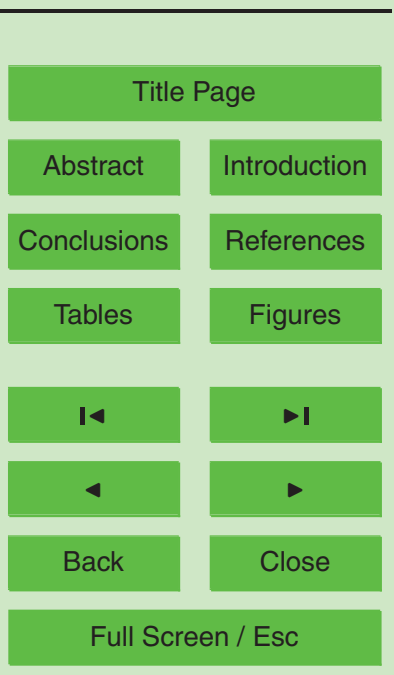

Printer-friendly Version

Fig. 6. Map of the Bistrita basin and the main sub-basins.

Interactive Discussion 


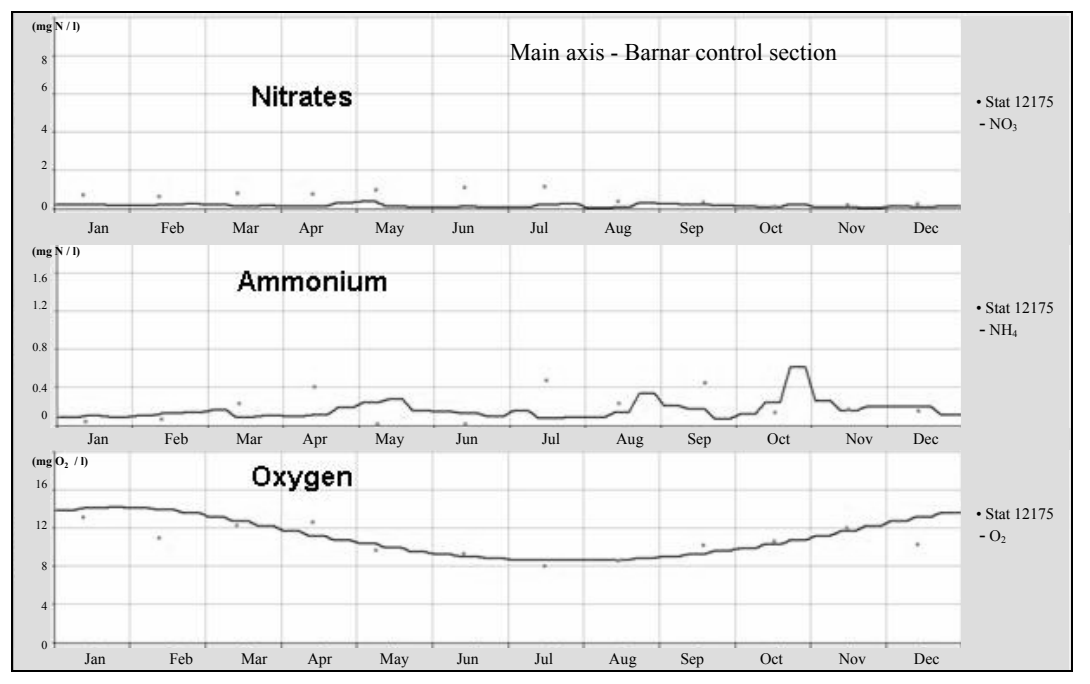

HESSD

4, 2035-2071, 2007

\section{Open-GIS decision} aid system for the Bistrita River Basin

M. C. Trifu et al.

Title Page

Abstract

Conclusions

\section{Tables}

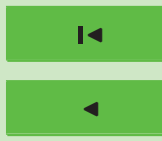

Back
Introduction

References

Figures

$\rightarrow 1$

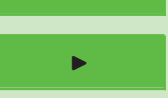

Close

\section{Full Screen / Esc}

Printer-friendly Version

Interactive Discussion

Fig. 7. Seasonal variations of discharge, nutrients (NO3, NH4, Ptot) and oxygen for 2000 year. The simulations are compared with the observations. 


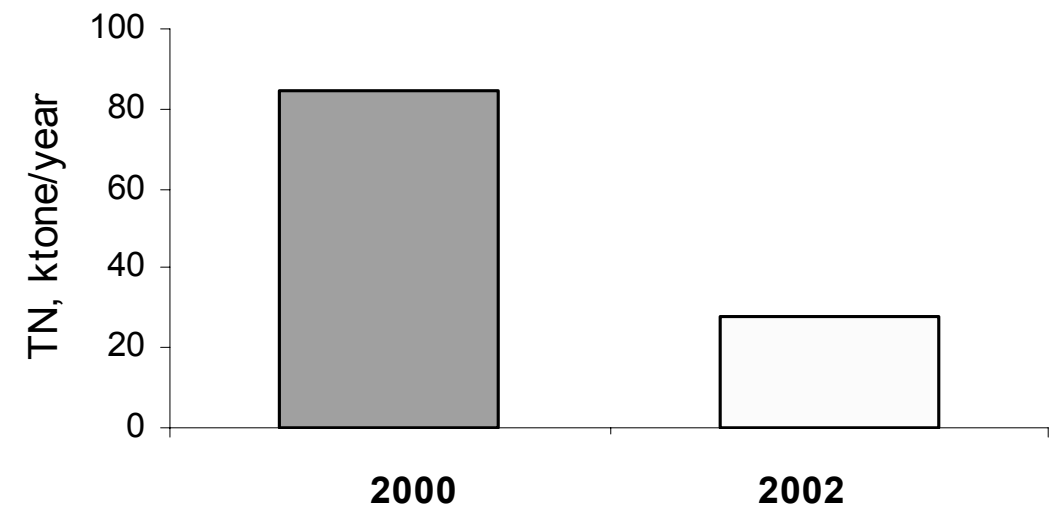

HESSD

4, 2035-2071, 2007

Open-GIS decision aid system for the Bistrita River Basin

M. C. Trifu et al.

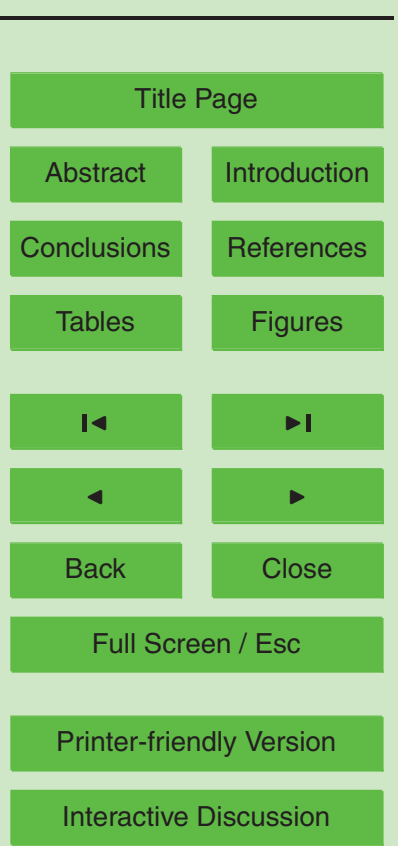

Fig. 8. Total nitrogen and phosphorous budget for 2000 (dry year) and 2002 (wet year) for the entire analyzed area. 


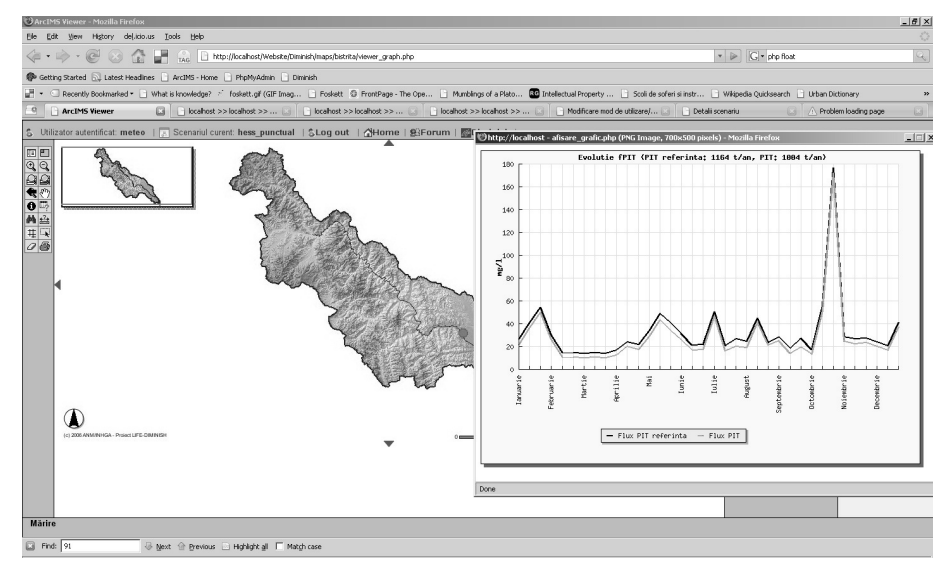

a)

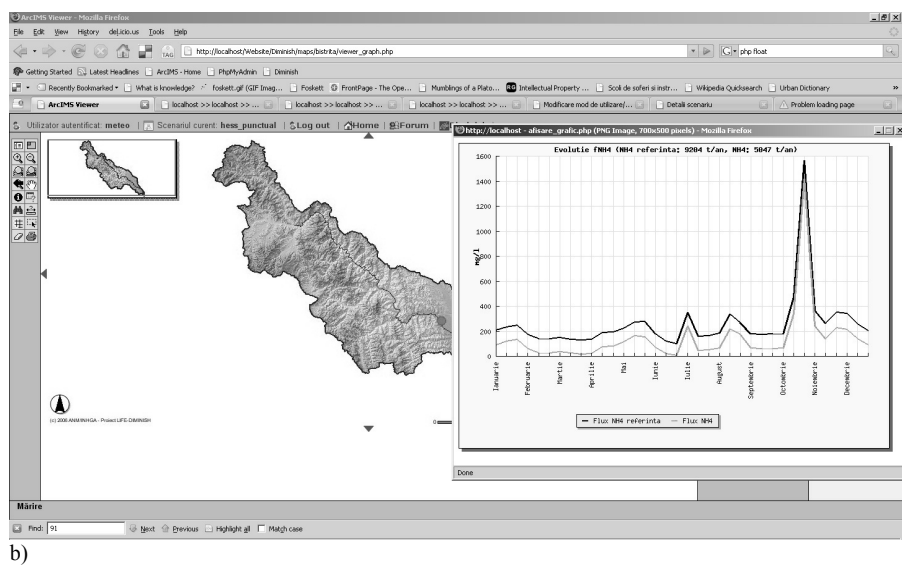

Fig. 9. Variations of the total phosphorous concentrations (a) and ammonium (b) before (dark line) and after (green line) the applied measure, linked to the reduction of point sources. (Capture from the Diminish system).

\section{HESSD}

4, 2035-2071, 2007

Open-GIS decision aid system for the Bistrita River Basin

M. C. Trifu et al.

\section{Title Page}

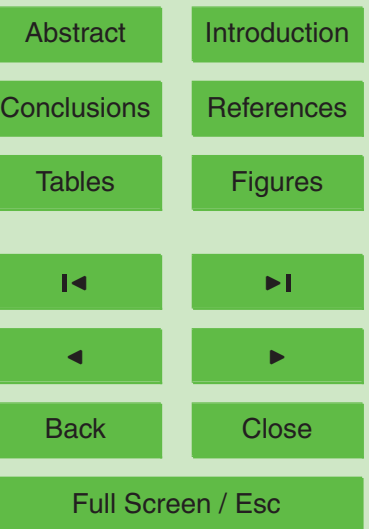

Printer-friendly Version

Interactive Discussion 


\section{HESSD}

4, 2035-2071, 2007

\section{Open-GIS decision aid system for the Bistrita River Basin}

M. C. Trifu et al.
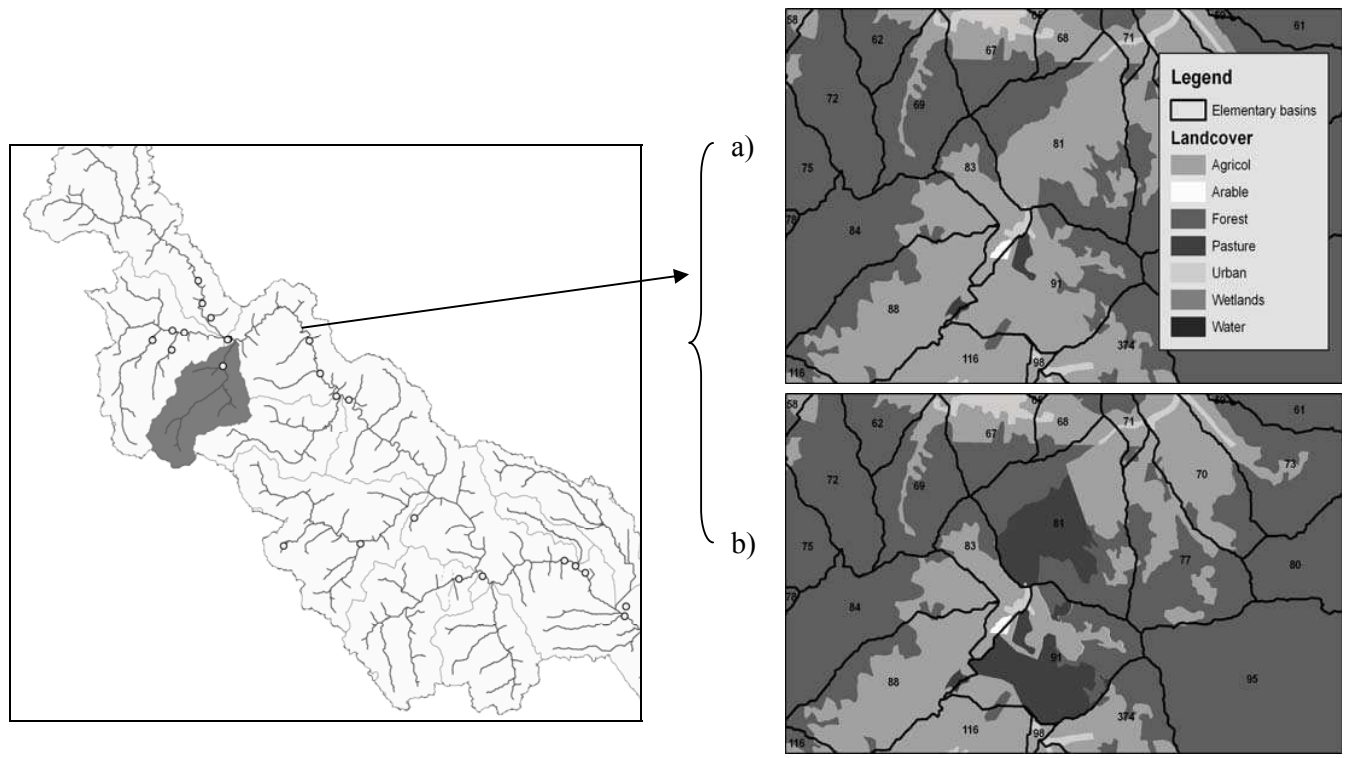

Fig. 10. Land use within the Neagra Sarului basin for the elementary basins no. 81 and 91: (a) actual situation - agriculture (light grey area); (b) tested scenario - change of agriculture into pasture (dark grey area).

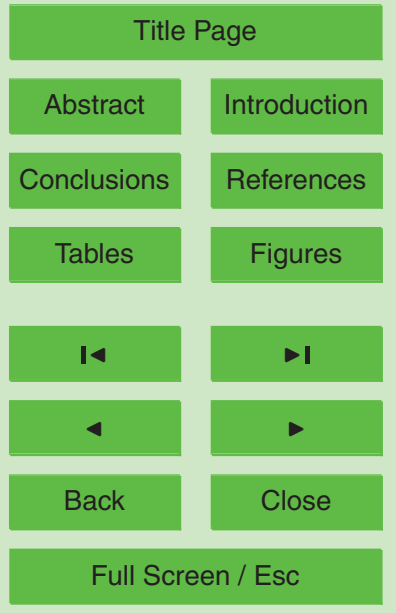

Printer-friendly Version

Interactive Discussion 
HESSD

4, 2035-2071, 2007

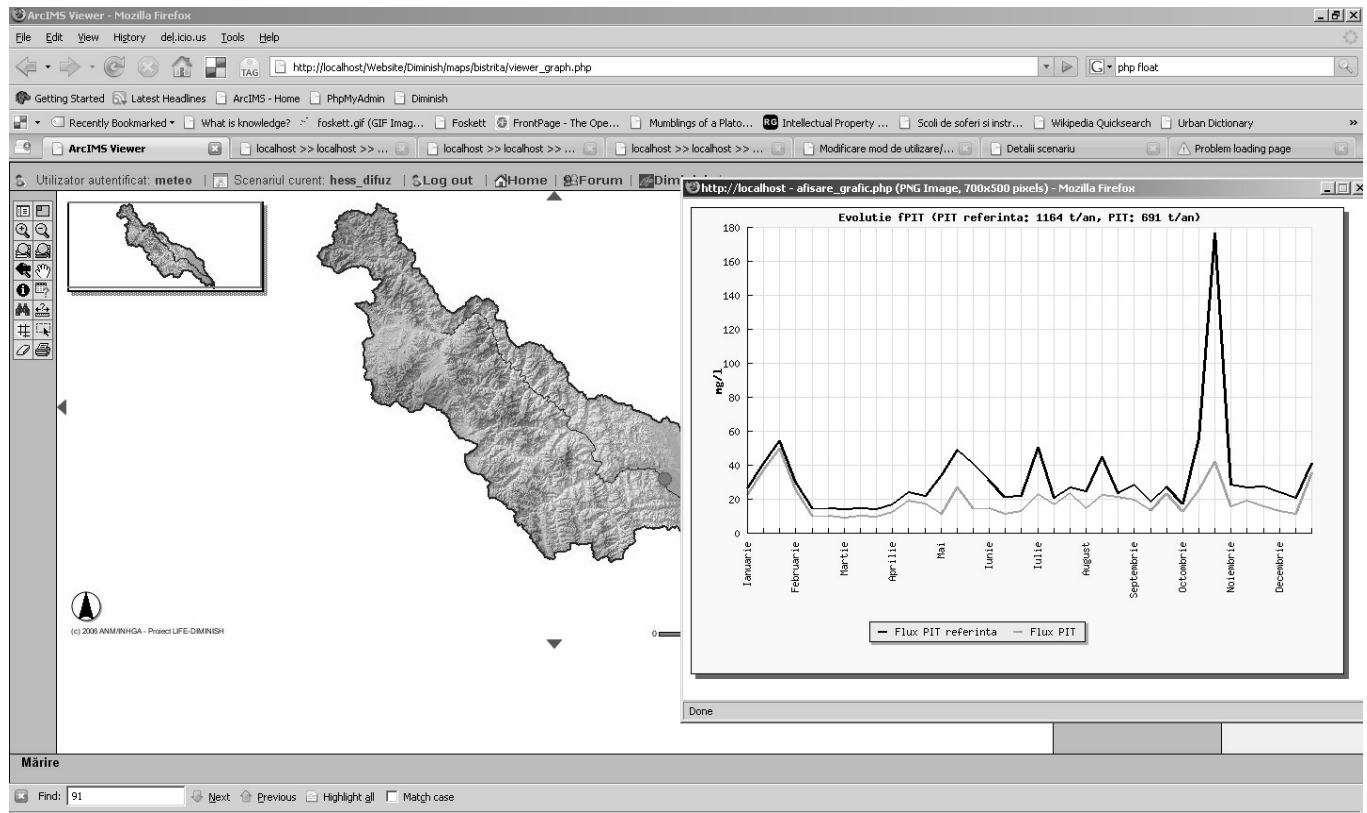

Open-GIS decision aid system for the Bistrita River Basin

M. C. Trifu et al.

Title Page

Abstract Introduction

Conclusions

References

Tables

Figures

14

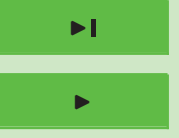

Back

Close

\section{Full Screen / Esc}

Printer-friendly Version

Interactive Discussion 


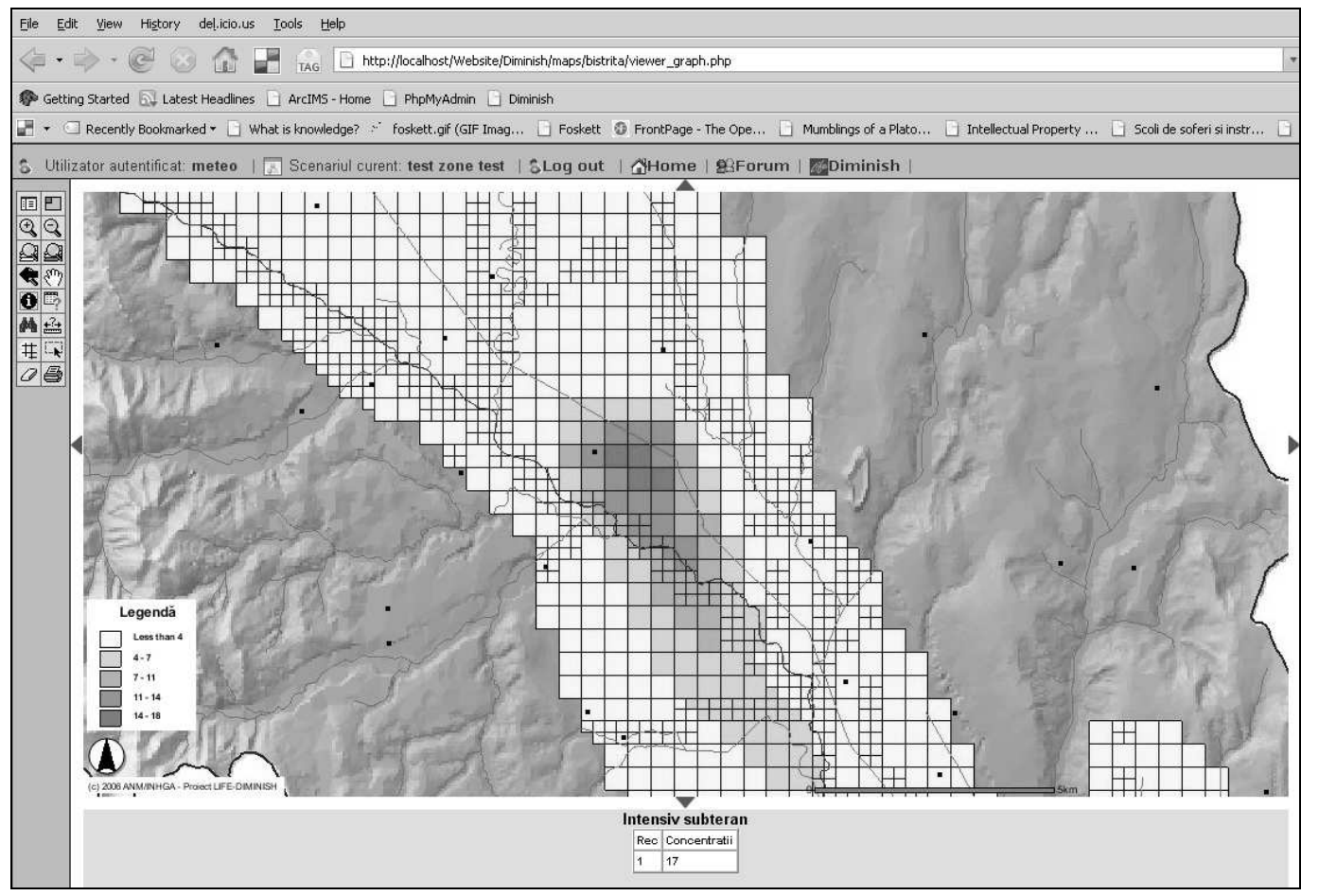

Fig. 12. Nitrate concentrations within aquifer in corn culture area $(\mathrm{mg} / \mathrm{l})$. (Capture from the Diminish system).

\section{HESSD}

4, 2035-2071, 2007

Open-GIS decision aid system for the Bistrita River Basin

M. C. Trifu et al.

\section{Title Page}

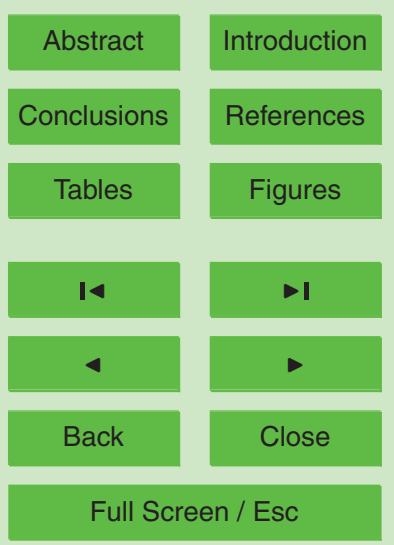

Printer-friendly Version

Interactive Discussion

EGU 


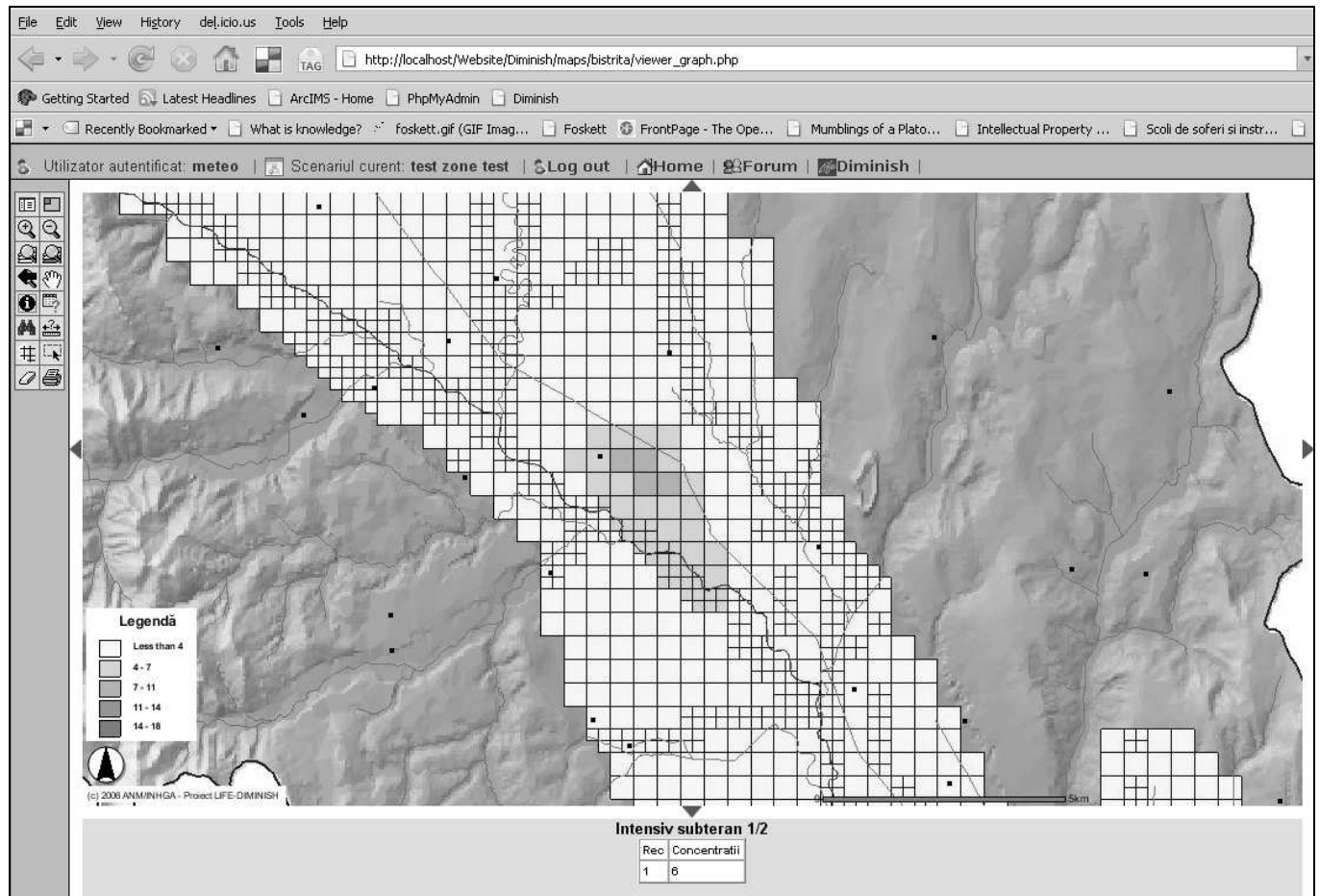

Fig. 13. Nitrates concentrations within aquifer in potatoes culture area $(\mathrm{mg} / \mathrm{l})$. (Capture from the Diminish system).
HESSD

4, 2035-2071, 2007

Open-GIS decision aid system for the Bistrita River Basin

M. C. Trifu et al.

Title Page

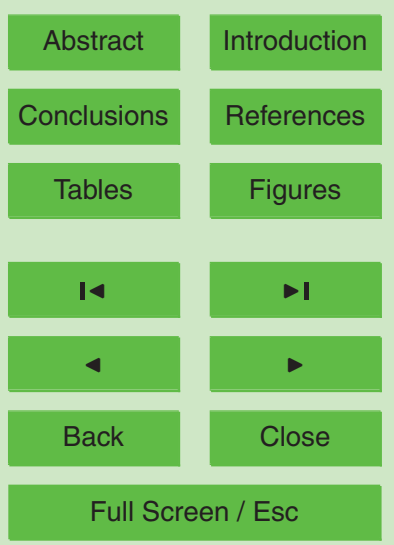

Printer-friendly Version

Interactive Discussion

EGU 